\title{
Impact of Weather Conditions on In Situ Concrete Wall Operations Using a Simulation- Based Approach
}

Robert Larsson and Martin Rudberg

The self-archived postprint version of this journal article is available at Linköping University Institutional Repository (DiVA):

http:/ / urn.kb.se/ resolve?urn=urn:nbn:se:liu:diva-158044

N.B.: When citing this work, cite the original publication.

Larsson, R., Rudberg, M., (2019), Impact of Weather Conditions on In Situ Concrete Wall Operations Using a Simulation-Based Approach, J ournal of construction engineering and management, 145(7), 05019009. https:/ / doi.org/ 10.1061/(ASCE)CO.1943-7862.0001662

Original publication available at:

https:// doi.org/ 10.1061/ (ASCE)CO.1943-7862.0001662

Copyright: American Society of Civil Engineers

http:/ / www.asce.org/ 


\title{
STUDYING THE IMPACT OF WEATHER CONDITIONS ON IN-SITU CONCRETE WALL OPERATIONS USING A SIMULATION BASED APPROACH
}

\author{
Robert Larsson \\ Ph.D. Student, Structural Engineering \\ Dep. Building \& Environmental Technology, Lund University \\ 22363 Lund, Sweden \\ robert.larsson@kstr.lth.se \\ and \\ Martin Rudberg \\ Professor, L E Lundberg Chair in Construction Management and Logistics \\ Department of Science and Technology \\ 60174 Norrköping, Sweden \\ martin.rudberg@liu.se
}

\begin{abstract}
The purpose of this research is to study the impact of temperature, precipitation and wind speed on in-situ concrete wall operations, and its combined resulting effect on project duration. The research presented is anchored in the learnings gained through a literature review on weather effects on construction operations, an analysis of weather data with high resolution and two field studies of in-situ concrete wall operations. These learnings are implemented in a discrete event simulation (DES) model for the analysis of weather impact on project duration. The simulation results show that 1) weather greatly impacts project duration and has to be accounted for when planning operations, 2) there are huge differences between weather seasons which could affect the timing of project startup, and 3) the height of buildings and threshold values for different types of cranes have to be accounted for when planning lifting operations. The main contribution of this paper lays both in the methods, in which high resolution weather data can be incorporated in DES models to analyze project duration, and in the actual results of the simulation runs, showing to what level weather variables have to be incorporated in the planning of concrete wall construction.
\end{abstract}

\section{INTRODUCTION}

The productivity of construction operations can be affected by many factors, of which weather is one that may cause disruptions, delays, and cost overruns in construction projects (Christian and Hachey 1995; Thomas and Ellis 2009; Nguyen et al. 2010). Low temperature, rain, etc., hampers the workers' ability to perform optimally, but also other resources, like machinery, may be affected. For example, strong winds may result in that cranes cannot be used for safety reasons. Due to the size of building sites and the fact that they change in layout as the construction evolves, it is not easy to employ measures to shield production against weather. Consequently, weather must always be accounted for when planning construction works and it is necessary to 
adjust productivity data for specific weather conditions to get reliable project duration and cost estimates.

Previous research studies have focused on how different weather parameters influence productivity, many of them with a focus to establish relationships between weather parameters and labor productivity. Three main weather parameters seem to be of main interest; temperature, precipitation, and wind speed, where the former two have gotten the most attention (see e.g. Koehn and Brown 1985; Thomas, Yiakoumis 1987; Thomas et al. 1999). Fewer studies have focused on the effect of wind speed, despite the fact that it is pointed out by industry experts as an important factor to consider (Watson 2004). One exception being the study by Moselhi and Khan (2010), analyzing the effects of wind speed on formwork productivity. Based on existing weather-productivity relationships, attempts have also been made to estimate and predict construction project duration under varying contextual conditions, see e.g. Moselhi et al. (1997), Ballesteros-Perez et al. (2015), Shahin et al. (2011) and Jung et al. (2016).

However, these projects have addressed weather conditions on a more general level. For instance, the weather data used are based on monthly or, at the best, on daily average values. Unfortunately, even daily aggregate level of data is limited to describe the natural daily variations of weather variables, and how this affect the productivity of construction projects. Temperature is normally lower at night, the intensity of precipitation or wind speeds may vary on hourly basis, etc. Obviously, the most interesting time span is to consider weather conditions during actual working hours and to link current weather conditions with specific work tasks. Today, weather data with higher resolution (hourly basis) can easily be accessed from meteorological databases. This enables to study the effects on a more detailed level (work tasks hour by hour) and thereby provide better predictions.

In this research, a discrete-event simulation-based approach is used to study how weather conditions, on an hourly basis, affect construction operations and project duration. Furthermore, this research will focus on construction of in-situ concrete walls. Forming and pouring concrete on-site is a frequently used method in many types of construction projects (Illingworth 2000). It is also typically time-critical in order to sustain the planned production cycle and it is exposed to all three main weather parameters: temperature, precipitation and wind speed. Examples being erecting and stripping of formwork, pouring concrete, use of crane for lifting formwork, and curing process of concrete. Any daily deviation in the construction of the concrete walls may increase the production cycle, and thereby jeopardize the overall project schedule and cost budget.

Hence, the purpose of this research is to study the impact of weather conditions on construction operations using a simulation based approach. More specifically, the impact of temperature, precipitation and wind speed on in-situ concrete wall operations will be studied, and their combined resulting effect on project duration. Within this purpose, the following research questions (RQs) will be addressed:

RQ1: How do different weather variables affect construction productivity?

RQ2: How can the effect of weather variables be described and analyzed using a simulation-based approach?

RQ3: How is construction productivity (measured as total project duration), affected by different weather conditions and seasonal variations? 
The results of this research contribute to the knowledge of how weather conditions affect the duration of construction operations. In contrast to earlier research, the proposed simulation based approach is more detailed in its description of construction operations and it also uses combined weather parameters on hourly basis. This allows for natural daily variations in weather parameters and thus increases the accuracy in estimations of the influence of weather on construction projects. The presentation of the research in this paper is structured in the following way. First, the research process is described presenting in detail the work undertaken. Thereafter, the problem background is presented describing the concept of baseline productivity followed by a review of previous work related to how weather affects construction efficiency. Next, the two field studies are presented in where real process data and knowledge are captured, necessary for model development. This is followed by a detailed description of the simulation model, its components, and how the effect of weather on construction work tasks are considered. Weather data analysis together with input data and simulation model validation are also described. The following two sections describe the work with designing the simulation experiments and the results. The next following section is devoted to analyzing and discussing the results. Finally, conclusions, including recommendations for future work, are provided.

\section{RESEARCH APPROACH}

The research approach is outlined in Figure 1. The research process contains five main steps, each described in more detail in this section. Steps 1-3 are used as input to steps 4 and 5. Steps 12 are related to RQ1 above, whereas step 4 is related to RQ2. Step 4 is used as a basis for the simulation experiments in step 5, which is used for answering RQ3.

*** Insert Figure 1 approximately here ***

\section{Literature review, weather data and field studies}

In the first step, the theory of baseline productivity (Thomas and Zavrski 1999) was studied in order to estimate ideal work productivity (1.1 in Figure 1), to which then effects of weather parameters could be added. Then, a literature review focusing on studies treating weather-related effects (1.2 in Figure 1) on construction productivity was conducted, including both scientific papers and technical reports. These two parts formed the theoretical base for how the effects of weather conditions should be treated in this study.

Based on the knowledge gained in step 1, it was concluded that temperature, wind speed and precipitation are the most significant parameters affecting construction productivity. However, depending on the geographical location of construction sites the weather conditions will naturally vary to a great extent. Since the field studies (step 3) were conducted in Sweden in the northern parts of Europe, cold temperatures and precipitation in terms of snow fall might come at play. Accordingly, in step 2 climatic data sets including these parameters were obtained from the Swedish Meteorological and Hydrological Institute (SMHI). The data sets covered hourly readings for the past 20 years for the city of Stockholm in Sweden. With the assist of SMHI, the data sets were statistically analyzed in order to identify which year that could either be conceived as a normal year considering all three weather parameters, or as an extreme year considering one of the parameters at a time. As a final step, each data set was controlled with respect to completeness of data readings and formatting the data so it could be used in a simulation model (step 5). Using data sets representing Swedish weather conditions naturally limits the 
generalizability of the study results. However, other climate data sets could be used in the simulation model doing similar analyses for other parts of the world.

Field studies of two projects (A and B) were carried out in step 3. In both studies the process of concrete wall construction was documented by on-site observations and from interviews with field experts. The two projects involved construction of multifamily buildings with similar structural design using similar construction methods, and due to the timing of the field studies the two projects were used slightly different to get a rich picture of the construction processes and data. For instance, in project A, handling of formwork panels and details about wall construction sequence and resource usage were documented. In project B, on-site time studies were carried out to collect work tasks' productivity data. The productivity values from project B were compared with other similar studies, and also discussed with field experts involved in project A to confirm the validity of the measured productivity rates. Moreover, project A was also used for model validation (step 4) and as a reference case during the simulation experiments (step 5).

\section{Simulation model development and simulation experiments}

Based on the knowledge gained from steps 1-3, a simulation model was developed in step 4. The model contains a detailed description of the construction work tasks and the use of resources, focusing on construction of in-situ concrete walls. It also contains specific relationships derived based on the productivity study. The relationships were used to determine the effect on work task productivity for varying weather parameters and the overall impact on project duration. Typical methods for verification and validation of the simulation model were employed, e.g. use of the software's integrated functions in order to test the logical behavior. For instance, stepwise animation of logical sequences, and use of embedded blocks to extract critical process data at certain points in the model structure. Finally, the simulated output was compared with the actual process documented in field project $\mathrm{A}$.

The effect of weather conditions on work task productivity and total project duration were studied by simulating a number of scenarios in step 5 . To facilitate a systematic approach, a matrix was developed describing the conditions for each scenario. Based on this matrix, each scenario was simulated separately under highly controlled conditions. The simulated results were compiled and analyzed, leading to conclusions on how weather conditions might impact construction operations, productivity and project duration.

\section{Reflections on the research approach}

Discrete-event simulation (DES) was chosen since it offers powerful capabilities to describe and analyze complex systems in a controlled and precise environment (Lucko, et al. 2008; AbouRizk et al. 2011). Influencing factors, e.g. weather, can be altered systematically and different scenarios can be studied in a very short time. An important feature of DES is to perform what-if scenarios based on stochastic input data. In this research however, the simulation model was run with deterministic inputs. One reasons was that the methodology used to calculate the effect of weather in the simulation model were deterministic. Another reason was that climatic data sets based on hourly records were used. It was not possible to create a weather function that could provide hourly values based on a statistical distribution. The research is limited in that it only focus on one project phase (erection of load bearing concrete walls) using climatic data from one country. However, erection of the load bearing structure is a crucial part in all building projects 
and due to the design of the simulation model, climatic data sets for other countries could easily be incorporated in the simulation model. Hence, the results of the simulation are reasonably general and could be extended with other geographical regions in future studies.

\section{PROBLEM BACKGROUND}

\section{Baseline productivity}

Productivity is affected by multiple factors simultaneously. Hence, it is difficult to determine the productivity effect of a single input factor. To deal with this problem, Thomas and Zavrski (1999) introduced the concept of baseline theory (Figure 2). The idea is to determine the ideal productivity (baseline) for a specific project. This baseline is considered to reflect the best performance possible within a specific project, defining an ideal situation with no significant disruptions. Baseline productivity is considered to be affected only by actual work complexity. To determine baseline productivity for a specific project, it is reasonable to consider work complexity as a constant. By adding disruptive factors (one by one) to the baseline, it is possible to describe the effect of a single factor, e.g. weather conditions, on productivity. The theoretical procedure to determine baseline productivity for a specific project is described in Thomas and Zavrski (1999). In principal, baseline productivity is determined for a specific project (or work tasks within a project) using the following steps: Step 1: Define the size of a subset by selecting a percentage of the total number of daily productivity measurements. According to Thomas and Zavrski (1999), a reasonable percentage value is $10 \%$. Step 2: Round this number to the next highest odd number. This number $n$ should not be less than 5 . The variable $n$ defines the size of (number of days in) the baseline subset. Step 3: The content of the baseline subset is selected as the $n$ days with the highest measured (or observed) productivity. Step 5: The baseline productivity is the median of the measured productivity in the baseline subset.

\section{*** Insert Figure 2 approximately here $* * *$}

More recently, another study have proposed an alternative definition and procedure to establish baseline productivity (Jarkas et al. 2015). However, in this study, baseline productivity is defined as a range where productivity varies under normal conditions. Consequently, this does not reflect an ideal situation since the productivity is assumed to be influenced under normal circumstances by multiple types of factors. It is believed that the baseline theory according to Thomas and Zavrski (1999) is better suited to use as a basis for describing the effect of a specific factor as described earlier.

\section{Weather effects on construction productivity}

By reviewing the literature focusing on studies analyzing weather-related effects on construction productivity, it was possible to identify the most significant weather factors. Table 1 provides an overview of the identified references used in this study, showing that temperature, precipitation and wind are the most important factors to include in the study. Each of these weather factors will be described in more detail below.

*** Insert Table 1 approximately here *** 
Not only humans, but also material and equipment could be affected by temperature (Shahin et al. 2011; Jung et al. 2016). For instance, the curing process of concrete slows down when temperature decreases. The influence of temperature on construction labor productivity is relatively well documented. Productivity is affected both at low and high temperatures. Unpleasant temperatures affects humans, not only physiologically but also psychologically. Physiologically, high temperature may lead to heat stress or dehydration among individuals. At cold temperatures, workers may experience general body cooling or tissue damages (Holmér 1994) and reduced finger and hand dexterity (Mäkinen et al., 2005). The cooling effect of wind speed and low temperature in combination also increases the risk of health effects and air humidity affects productivity both at high and low temperatures.

The effect of temperature and humidity on construction worker's productivity was explored in Koehn and Brown (1985). It was found that temperatures between 10 and $25{ }^{\circ} \mathrm{C}$ (50 and 77 ${ }^{\circ} \mathrm{F}$ ) did not have any significant effect on productivity at normal humidity levels (about $60 \%$ ). However, at colder or hotter temperatures, the effect is considerable. In a following study, Thomas and Yiakoumis (1987), claimed that temperatures between 10 to $15{ }^{\circ} \mathrm{C}$ (50 to $59{ }^{\circ} \mathrm{F}$ ) were optimal in terms of work efficiency. Another study by Hassi (2002) stated that a temperature around $10^{\circ} \mathrm{C}\left(50{ }^{\circ} \mathrm{F}\right)$ has no impact on labor productivity, but significant effects on productivity were noticeable when temperature rises above $20{ }^{\circ} \mathrm{C}\left(68{ }^{\circ} \mathrm{F}\right)$ or drops below $-5{ }^{\circ} \mathrm{C}$ $\left(23^{\circ} \mathrm{F}\right)$. A more recent study presented in Moselhi and Khan (2010) suggests that an optimum temperature interval in terms of productivity is between 14 and $18{ }^{\circ} \mathrm{C}$. Thomas and Ellis (2009) estimated that cold temperatures below $-7^{\circ} \mathrm{C}\left(19{ }^{\circ} \mathrm{F}\right)$ resulted in a $50 \%$ productivity loss while hot temperatures above $29{ }^{\circ} \mathrm{C}\left(84^{\circ} \mathrm{F}\right)$ resulted in a $40 \%$ loss. In Figure 3, the relationships between temperature and productivity based on three of the mentioned studies are presented.

\section{*** Insert Figure 3 approximately here $* * *$}

In the Figure, a productivity factor (Y-axis) equal to one means no loss in productivity due to temperature. Accordingly, a factor equal to zero means $100 \%$ loss in productivity (work stoppage). As seen in the Figure, the estimated productivity loss based on Koehn and Brown and Mosehli and Kahn are relatively equal, whereas Hassi indicates lower effects at cold temperatures and higher effects at warm temperatures.

\section{Influence of precipitation}

Rain and snow also hamper labor productivity, since workers have to spend time on actions to cover materials and work areas. Precipitation also has a negative effect of work performance in general, and precipitation in combination with cold temperatures can also cause slip and fall accidents (Jung et al. 2016). Moreover, a snowfall on an unprotected work area requires additional time for shoveling and cleaning. If the intensity of a rain or snowfall becomes too high, the work may have to stop and Jung et al. (2016) state that precipitation is the weather factor that causes most work stoppages.

Several studies have reported that labor productivity is affected by precipitation even at light or moderate intensity. For instance, Moselhi and Khan (2010) reports that light rain or snow results in a $40 \%$ loss in productivity. Noreng (2005) reports that a rainfall with intensity of 4 
mm (per 12 hours) causes $65 \%$ productivity loss. The effect of snowfall is reported to vary between $10 \%$ and $60 \%$ depending on intensity. Thomas and Ellis (2009) conclude that the loss of productivity due to rain or snow is between 50-60\%. Other studies have defined threshold values for when productivity is affected by precipitation. For instance, Ballesteros-Perez et al. (2015) state that a daily rainfall more than $10 \mathrm{~mm}$ rainfall causes a loss in productivity when pouring concrete. Another study reported by Jung et al. (2016), state that precipitation with intensity of $5 \mathrm{~mm}$ per hour results in work stoppage of concrete placement. Birgisson (2009) argues that construction works on a horizontal surface are more sensitive to precipitation compared with a vertical surface.

Figure 4 presents a summary of, how construction efficiency is affected by precipitation intensity. The numbers in the diagram are based on documented studies. The red dotted line is a simplified approximation of the influence on efficiency as a function of precipitation intensity. The approximation is based on mean values for each of the intervals of precipitation intensity as indicated by the vertical lines in Figure 4.

$$
\text { *** Insert Figure } 4 \text { approximately here *** }
$$

\section{Influence of wind speed}

The influence of wind on lifting operations depends on a combination of factors, such as wind speed, height of lifting operation, ambient terrain, and type of objects to be lifted. For instance, lifting operations of large light-weight formwork panels are more affected by wind compared to lifting heavy rebar bundles. Wind also affects workers at higher altitudes. Strong gust winds increase the risk of accidents and may require additional safety measures.

The most comprehensive study of the influence of wind speed was reported in Moselhi and Khan (2010). Here, wind was studied as one of several factors influencing formwork operations. It was concluded that wind speeds about $12 \mathrm{~m} / \mathrm{s}$ reduce formwork productivity with $17 \%$. Other studies, e.g. Noreng (2005), indicates a 20-25\% productivity loss at wind speeds above $10 \mathrm{~m} / \mathrm{s}$. A study by Birgisson (2009), concluded that wind speeds between 8-14 m/s reduce formwork productivity with $20 \%$. Ballesteros-Perez et al. (2015) points out that handling of formwork is started to be affected at wind speeds above $5 \mathrm{~m} / \mathrm{s}$.

For safety reasons, there also exist recommendations for maximum wind speeds at where crane usage are not allowed. In general, maximum wind speed for crane usage is dependent on several factors; crane type, height, wind direction, surrounding terrain and type of load to be lifted (surface, weight). According to international crane manufacturers, in-service wind speeds are in general up to $20 \mathrm{~m} / \mathrm{s}$ for modern tower cranes (Watson 2004). For mobile cranes, inservice wind speeds up to $14 \mathrm{~m} / \mathrm{s}$ are typically recommended. However, these recommendations may vary somewhat between countries and manufacturers. Some manufacturers provide additional information of maximum wind speeds considering the weight and size of the load to be lifted (Liebherr 2012). As a complement to manufacturer recommendations, there may also exist local industry praxis and agreements on maximum wind speed for specific lifting operations. In Sweden, for instance, lifting large formwork panels are normally avoided at wind speeds above $15 \mathrm{~m} / \mathrm{s}$ (Andersson 2017, Jönsson 2016). In Jung et al. (2016), maximum wind speeds of $10 \mathrm{~m} / \mathrm{s}$ are used as a threshold value for cancelling lifting of curtain walls and pouring 
concrete using crane and skip. In a study reported by Shahin et al. (2011), the crane stoppage condition was set to wind speeds above $14 \mathrm{~m} / \mathrm{s}$

Figure 5 gives an overview of the documented relationship between wind speed and loss in productivity together with thresholds for both recommended and maximum allowed wind speeds for lifting operations.

$$
\text { *** Insert Figure } 5 \text { approximately here } * * *
$$

\section{Summary of weather effects}

A summary of weather effects on construction activities based on reviewed reports is presented in Table 2. It can be noted that relatively small changes in some weather factors may have significant impact on work efficiency. For instance, a small increase in precipitation intensity may reduce work efficiency by $40 \%$ or increasing wind speed above $14 \mathrm{~m} / \mathrm{s}$ may cause a work stoppage for some lifting operations. It is therefore necessary to describe these relations as detailed as possible, e.g. by describing effects of weather factors on individual work tasks using climatic data sets with hourly resolution. In this paper, the relationships presented in Figures 3-5 are used as a basis to describe how weather parameters influence losses in efficiency for different work tasks. A description of how these relationships are incorporated into the simulation model is described in section "Procedure for considering weather conditions". Specific values on the weather-productivity functions that are used when performing the simulation experiments are outlined in Table 6.

*** Insert Table 2 approximately here ***

\section{FIELD STUDY PROJECTS}

Two projects (A and B) were used to gain knowledge about the construction process of in-situ concrete walls. An overview of the project characteristics and description of data collection activities is outlined in Table 3.

*** Insert Table 3 approximately here ***

\section{Description of construction process and formwork management}

The construction sequence of in-situ concrete walls consists of a set of work tasks carried out both sequentially and simultaneously. The construction sequence is typically cyclical and repeats itself on a daily basis. A sequence starts with erecting the first side of formwork. When finished, box outs for openings are mounted onto the panels. Simultaneously, sub-contractors place pipes and outlets. Rebars are then mounted and fixed. When all rebars are in place, the second side of formwork are erected and then concrete is poured. The formwork are then stripped when the concrete walls have reached sufficient strength. Formwork panels are then moved to the next position where the sequence starts over again. The construction sequence documented in the field studies is schematically illustrated in Figure 6. 


\section{*** Insert Figure 6 approximately here $* * *$}

Moreover, the start of a work task is dependent the of output from a preceding activity. This dependency is indicated by start condition $\mathrm{X}$ and $\mathrm{Y}$ in Figure 6. For instance, pour concrete (work task 6) is allowed to start when work task 5 has finished formwork erection for all walls subjected to a particular wall phase. Start condition $\mathrm{Y}$ enables an overlapping processing. For instance, fix rebars (work task 4) is allowed to start when one wall has been completed by work tasks 2 and 3 respectively. It should be noted that on a general level, the starting conditions may vary from project to project.

The most important work tasks involve handling of the formwork system which include preparations, erection, stripping, and movement to the next work location. The walls on a floor plan are divided into groups (wall phases). The division of wall phases and the formwork handling scheme in field project A are illustrated in Figure 7, where each floor plan consists of four wall phases with a varying number of walls.

*** Insert Figure 7 approximately here ***

The first number in brackets represents wall phase number (overall sequence) and the second number represents the construction sequence of walls within each phase. The denotations F1 to F4 represent different types (sizes) of formwork panels. Since the formwork panels are shared between the two buildings, they are moved between these as indicated by the two opposing arrows. When the walls in the last wall phase are completed in building 1 , the formwork panels are stripped and lifted to building 2 . Here, the work sequence starts over until all walls are finished and the formwork is moved back once again. The procedure is repeated until all floors in the two buildings are finished.

\section{Estimation of baseline productivity}

Labor productivity for each work task (as described in Figure 6) was collected by time study observations in field study B. The measurements were carried out during a period of five weeks. A standardized time study collection form was used where resource usage, work quantities and man hours for each activity was documented. The collected data was used to determine labor productivity and also for estimation of baseline productivity according to Thomas and Zavrski (1999). As an example, a copy of data collection of labor productivity for pouring concrete walls is given in Figure 8. In the Figure, the baseline subset and the determined baseline productivity are displayed. Baseline productivity data for remaining work tasks according to Figure 6 were estimated in the same way and are given in Table 4.

*** Insert Figure 8 approximately here ***

*** Insert Table 4 approximately here $* * *$ 


\section{SIMULATION MODEL DEVELOPMENT}

\section{Model description}

The simulation model was implemented in ExtendSim AT (version 9.2), which is a generalpurpose discrete-event simulation software (www.extendsim.com). More details about the simulation software and how it works can be found in for example Krahl (2003) and Schriber et al. (2013). A schematic illustration of the simulation model and its components is illustrated in Figure 9. An essential part of the model is the logical description of the workflow. The model is hierarchical using ExtendSims's pre-defined construct block elements to describe project's characteristics, including workflow and the use of resources, and for import and export of data. In the example in Figure 9, the construction setup for field study A is shown.

\section{*** Insert Figure 9 approximately here ***}

User defined data is imported at the beginning of the simulation from Excel-files and stored in internal databases. Data are retrieved depending on model update status during the run of the simulation. Simulation results are continuously logged and stored in output databases. Timing data of the simulated process can be retrieved both at an overall level (project duration), and at a work task level (daily output). The model also reports when the crane stops due to high winds and which activities that are affected. Simulation starts at a user defined date, and simulates the construction process until all walls have been completed.

\section{Procedure for considering weather conditions}

Another essential part of the simulation model is the algorithm for considering the impact of weather conditions on construction productivity, based on the findings from the literature review. The loss in productivity as a result of changing temperature is given by the variable $p_{\text {temp }}$ which is determined by the graphs in Figure 3. In the same way, $p_{\text {prec }}$ determines the productivity loss due to precipitation according to the approximated graph in Figure 4 . The loss in productivity due to increasing wind speed is given by the variable $p_{\text {wind }}$ which is determined by the graph in Figure 5 including thresholds for maximum allowable wind speeds for crane usage. These variables are used to dynamically calculate the productivity loss for a new set of climatic data during the run of a simulation. The influence on actual productivity is determined by multiplying the baseline productivity with a weather factor $(w f)$. The weather factor describes the combined effect of wind speed, temperature, and precipitation intensity (see equation 1).

$$
\begin{aligned}
& w f=p_{\text {wind }}(w) \times p_{\text {temp }}(t) \times p_{\text {prec }}(p) \\
& \text { Where: }
\end{aligned}
$$

$p_{\text {wind }}(w)$ defines the effect on productivity as a function of wind speed

$p_{\text {temp }}(t)$ defines the effect on productivity as a function of temperature

$0 \leq p_{\text {wind }}(\mathrm{w}) \leq 1$

$p_{\text {prec }}(p)$ defines the effect on productivity as a function of precipitation intensity

$w$ is wind speed $(\mathrm{m} / \mathrm{s}), t$ is temperature $\left({ }^{\circ} \mathrm{C}\right), p$ is precipitation intensity (mm/hour)

$$
\begin{aligned}
& 0 \leq p_{\text {temp }}(t) \leq 1 \\
& 0 \leq p_{\text {prec }}(p) \leq 1
\end{aligned}
$$

The weather factor ( $w f$ ) varies between 1 and 0 , where 1 indicates no loss in productivity due to weather effects and 0 means a 100\% loss in productivity (equal to work stoppage). In Figure 10, 
the overall procedure for considering the impact of weather conditions on construction duration is presented. The main steps are;

1) At every hour, actual weather conditions (wind speed, temperature, precipitation) are imported from the climatic database. The weather data is updated on hourly basis. Depending on actual temperature, the type of precipitation (rain or snow) is determined.

2) Wind speed is adjusted to current altitude at where construction work is taken place. This is done according to power law wind profile, see equation 2.

$$
w_{z}=w_{g} *\left(\frac{z}{z_{r e f}}\right)^{\alpha} \quad\left(0<z_{r e f}<z\right)
$$

where $w_{z}=$ wind speed at height $z ; w_{g}$ is measured wind speed at measured altitude $z_{r e f}$; and $\alpha=$ coefficient which is dependent on the surface type and atmospheric stability. According to (Şen et al. 2012), $\alpha$ is about 0.4 for urban areas.

3) Actual wind speed is then compared with maximum allowed wind speed for lifting operations. Threshold values are user defined and imported into the model at the beginning of the simulation. Different types of lifting operations can have different threshold values. Also, different thresholds can be defined for different formwork types, e.g. large panels may have a lower threshold value than panels with small surface area exposed to wind.

4) If wind speed is higher than maximum allowed wind speed, the model stops until next update of weather conditions.

5) If wind speed is lower than allowable wind speed, the effect on labor productivity is determined by the weather factor $(w f)$. If $w f$ is equal to zero, the work is stopped until next update of weather conditions.

$$
\text { *** Insert Figure } 10 \text { approximately here *** }
$$

\section{Weather data analysis}

Weather data was retrieved and analyzed in collaboration with the Swedish Meteorological and Hydrological Institute (SMHI). For a specific geographic location (Stockholm), data sets for five different climatic conditions were compiled based on a 20-years period (1997-2016) of weather data.

1. Normal: The year that had least deviation in annual precipitation, annual average temperature, and average wind speed compared with average values for the total period of 20 years. Based on the analysis, year 1997 was selected.

2. HighTemp: Year2014 was selected as it had the highest annual mean temperature.

3. LowTemp: Year 2010 was selected as it had the lowest annual mean temperature.

4. Windy: Year 2011 was selected as it had the highest average wind speed.

5. HighPrec: Year 2012 was selected as it had the highest annual precipitation.

For each year selected, wind speed, temperature and precipitation for every hour during a full year was compiled. Each data set was controlled for completeness. In cases of missing data points, they were completed manually by interpolating between nearby values. Since the weather data sets contain hourly data for each parameter, the simulation model accounts for weather 
effects at a detailed level. As a result, the variation of a weather parameter during a day is considered. This is illustrated in Figure 11 where wind speed variation during a 48 hour period is given. As seen, the actual wind speed varies and the actual hourly value may deviate from the average. In the same way, the model accounts for variable temperature, and precipitation intensity (rain or snow), that occur during working hours. In this way, the effect of weather can be estimated more precisely.

$$
\text { *** Insert Figure11 approximately here *** }
$$

\section{Input data and simulation model validation}

Validation concerns both analysis and quality check of input data as well as various methods for ensuring the reliability of the model itself. Validation of model inputs was done as an integrated part of the data analysis discussed in previous sections, e.g. weather-productivity relationships (section "Weather effects on construction productivity"), baseline productivity (section "Estimation of baseline productivity"), weather data (section "Weather data analysis").

According to Sargent (2013) validation of the simulation model concerns both underlying logic descriptions and comparison between simulated results and real world output. The logic description was closely examined and compared with the documented workflow as was observed in field studies. The process logic was then validated by stepwise simulating through a construction sequence. Critical steps were examined in detail with the help of ExtendSim's animation functionalities. As a final test, simulated project duration was compared with real process knowledge gained from field project A, consisting of 138 separate concrete walls divided in 48 wall phases. In order to facilitate analysis of the simulated output values, the model was run in an ideal mode with no impact of weather conditions and the results were analyzed and discussed with site managers from project A. It was concluded that the model was capable of reproducing the expected construction sequence both at a detailed level (daily output), and in terms of total project duration.

\section{SIMULATION EXPERIMENTS}

To study the effects of weather, project A was used as a reference with the construction process as described in Figure 6 and project layout in Figure 7.

\section{Design of experiments}

Five different weather conditions as described in section "Weather data analysis" were used in the simulation model and individual and combined effects of temperature, wind speed, and precipitation were simulated. For each scenario, also seasonal effects were considered by adjusting the construction start date: Winter (Win) to $1^{\text {st }}$ January, spring (Spr) to $1^{\text {st }}$ April, summer (Sum) to $1^{\text {st }}$ of July and autumn (Aut) to $1^{\text {st }}$ October. The simulated scenarios, in total 80 different scenarios, are given in Table 5. The effect of wind conditions was also further studied by changing the height of the building from six to ten floors as well as reducing allowable wind speed (from 15 to $11 \mathrm{~m} / \mathrm{s}$ ) related to lifting formwork.

$$
\text { *** Insert Table } 5 \text { approximately here *** }
$$


Table 6 summaries the relationships and thresholds used in the simulation model in order to describe the effect of weather variables on concrete wall activities. Note that for temperature, the relationship defined by Mosehli and Kahn (2010) is used for three reasons; 1) the relationship is based on continuous measurements over a long period of time; 2) it is also valid for formwork activities; 3) data was collected in climatic conditions similar to the Nordic countries. To describe the effect of precipitation given in Figure 4, the approximated function defined by the dotted line is used.

\section{*** Insert Table 6 approximately here ***}

Finally, specific project characteristics needed as model input are summarized in Table 7 and 8 . Also baseline productivity data according to Table 4 was used as model input.

\section{Results}

The effect of weather conditions are presented in Figure 12, with all values related to an ideal, baseline, situation with no effects from weather. As seen in Figure 12, temperature is the single most important weather parameter, followed by wind speed, and then precipitation. The effect of temperature under normal weather conditions results in a $35 \%(1,35)$ increase in project duration when the construction is taken place during the winter season (win). For the other seasons, the effect of temperature varies between $10-17 \%$. Worst case was found during the winter season for the year with the lowest annual mean temperature (+60\%), which is not surprising given that the weather data is collected in a country with cold winters. Similarly, the effect of temperature is reduced for the year with highest temperature compared with a normal year

\section{*** Insert Figure 12 approximately here ***}

Under normal weather conditions, the effect of wind is at the most during winter and spring season (10\% and $14 \%$ respectively). Somewhat surprising, the year with highest annual wind speed in average did not result in the largest effect on project duration. This further highlight the importance of using detailed weather data, rather than daily or weekly averages. It is the weather conditions during the actual working hours that matters. Precipitation was found to have the least effect on construction duration. Worst case occurs during autumn (12\%) for the year with lowest temperature. It should be pointed out that the year with highest annual precipitation only resulted in the largest effect during one of the seasons considered. Similar effects were also present for temperature and wind speed. Once again, this further promotes the use of hourly weather data during working hours, rather than averages for the different weather factors.

The combined effect of the three weather parameters indicates a $14 \%$ to $46 \%$ increase in project duration under a normal weather conditions, depending on season. Highest impact occurs, as expected, during the winter season. The effect during spring and autumn was found to be more or less equal (25 and 29\% respectively), whereas the combined effect of weather during summer indicates a $14 \%$ increase in project duration. When comparing the identified extreme years (high/low temperature, windy, high precipitation) with a normal year for the combined weather effects there are differences, but rather limited variations. For the year with high temperature, the project duration increases marginally (2.6\%) during summer period compared with normal weather conditions $(1,17 / 1,14)$, whereas it decreases for all other seasonal periods 
600

601

602

603

604

(by 5-12 \%). Once again, bear in mind that the weather data represents a cold country and high temperatures is normally positive during these seasons. For the year with low temperature, construction duration increases during winter (10\%), summer (3\%), and autumn (6\%) compared with normal weather. For the windy year, project duration increases during winter and autumn (by $5 \%$ and $6 \%$ respectively) compared with normal weather. However, project duration decreases during spring and it is unaffected during summer season. The year with highest annual precipitation also shows variations depending on season, but in general there are only moderate differences compared to the seasons of a normal year. In summary, one can conclude that there are large variations between seasons when looking upon the combined weather effects, but that the variations of extreme years compared to a normal year are smaller.

Turning to the effect of wind relative building height and thresholds for allowable wind speeds, the results are summarized in Figure 13. Here, only normal weather conditions have been simulated. For a six story building, changing the threshold from 15 to $11 \mathrm{~m} / \mathrm{s}$ for lifting formwork increases project duration during winter and spring season by 14 and $25 \%$ respectively. The total number of wind stop days increases to 2.9 days during winter and 3.5 days during spring. For a ten story building, the project duration increases to $32 \%$ during winter if maximum allowed wind speed for lifting formwork is set to $11 \mathrm{~m} / \mathrm{s}$. This is an increase by $14 \%$ compared with a threshold value equal to $15 \mathrm{~m} / \mathrm{s}$. Wind stop days increase from 3.6 to 17.6 days. Increased project duration could also be expected during spring and summer periods even though the effects are more limited.

$$
\text { *** Insert Figure } 13 \text { approximately here } * * *
$$

\section{ANALYSIS AND DISCUSSION}

The simulated results show to what level different weather conditions affect productivity. For instance, the simulation results indicate approximately a $30 \%$ longer duration if construction is taken place during winter compared to summer. These findings are in accordance with experiences based on follow-ups of construction projects in the Nordic countries (Larsson and Söderlind 2006). Another study reported a $35 \%$ loss in efficiency due to winter conditions (Thomas et al. 1999).

\section{Impact of weather conditions}

It was found that temperature is the single most important weather factor followed by wind speed and precipitation. This is well correlated with other studies, e.g. Moselhi and Khan (2012). Since temperature seems to be of such importance, it is important to carefully evaluate which temperature-productivity relationship to use. Referring to Figure 3, the three relationships value the effect on productivity due to cold and hot temperatures somewhat differently. This could be a result of geographical differences. It is not unlikely that construction workers in e.g. Nordic countries, as studied by Hassi (2002) are more adapted to cold temperatures than hot temperatures.

The wind speed was found to be the second most important weather parameter suggesting that it should be further investigated. As expected, the effect of wind becomes more important to consider when the height of construction increases. Also maximum threshold values for lifting operations strongly influence the number of wind stop days and in the end, the project duration. 
605

606

607

608

609

610

611

612

613

614

615

616

617

618

619

620

621

622

623

624

625

626

627

628

629

630

631

632

633

634

635

636

637

638

639

640

641

642

643

644

645

646

647

Consequently, identifying thresholds for different types of lifting operations (and loads) are important when considering the effects of wind speed. In addition, other crane types (mobile cranes) may have lower limits for maximum allowable wind speed (Liebherr 2012). Accordingly, wind speed becomes even more important to consider when using mobile cranes for lifting light-weight loads with large surfaces.

The intensity of precipitation (both rain and snow) that occurred during actual working hours did not have any significant effect on productivity. One can argue that precipitation that falls during night (or even days) prior to the actual working day should be considered as well. Other studies have employed such lingering effects (Shahin et al. 2011, Jung et al.), but in this particular case with wall construction, the effect of past precipitation is believed to be much more limited. Of course, a snowfall will definitely influence the productivity since workers have to spend time on shoveling and cleaning unprotected work areas, but that is more related to horizontal work areas such as floor slabs.

Considering the effects of varying weather conditions, it was found that more extreme weather can have both negative and positive effects on project duration depending on actual season for construction (winter, summer etc.). These findings suggest that attention should be devoted to exploring the effects of weather on construction considering more extreme conditions as well as seasonal variations.

\section{Accounting for weather conditions in project planning}

The results presented in this paper provide understanding of how construction projects may be influenced by weather during different contextual settings. This knowledge can be useful in different ways when planning construction projects. At a project level, the results can be valuable for making better estimations of project durations by accounting for weather more accurately. Implications on project duration can be analyzed by simulating different weather conditions, building characteristics, and construction start dates. The results can be used to verify that the construction plan is realistic considering the weather conditions that are expected during the time for construction. Productivity rates may also be adapted to various weather conditions or seasonal variations. It will also facilitate selection of necessary measures to shield production against weather in order to preserve a desired rate of construction. This also includes evaluation of suiTable methods and equipment in order to mitigate risks related to adverse weather. For instance, evaluating the risks of lifting operations and crane setup related to expected wind conditions. Improved accuracy in estimations of weather effects on project duration also enables for optimization. For instance, the need for buffers to manage weather related risks could be reduced, or even eliminated. On a short term perspective, the simulation model could be supplied with daily weather forecast data. In this way, simulated results can be used in order to validate the production plan for the next following work days, or even longer depending on the quality of the forecast.

\section{Research limitations}

The results presented in this paper are first of all valid for concrete wall construction under the effect of Swedish climate conditions, in particular the Stockholm region. However, using climatic data representative for other geographical areas, the effect of weather can be studied in a similar way. It should also be emphasized that the results are strongly dependent on the underlying relationships between weather parameters and labor productivity. If possible, each 
648

649

650

651

652

653

654

655

656

657

658

659

660

661

662

663

664

665

666

667

668

669

670

671

672

673

674

675

676

677

678

679

680

681

682

683

684

685

686

687

688

689

690

relationship should always be evaluated against own Figures or personal experiences. Increasing the empirical base by collecting more data in order to verify existing relationships or making new ones, is a priority for future research.

The model presented in this paper is limited to describe the effect of concrete wall operations. In order to estimate the duration of a concrete framework, other work tasks must be considered as well, e.g. curing of concrete, erecting horizontal formwork, and pouring concrete slabs. It is believed that such work tasks relatively easily could be incorporated into the existing model. However, other relationships and thresholds describing the effect of weather on concrete slab operations may then be required.

In spite of the mentioned uncertainties associated with the model itself and the input data used, it is believed that the combined measures of model and input data validation increase the confidence of the findings presented in this paper. For example, validation of input data through collection of real process data from field studies, review of underlying weather-productivity relationships, and the use of high quality weather data from trusted sources.

\section{CONCLUSIONS}

Weather is one important factor that has a negative effect on construction efficiency. Usually it is also related to uncertainties when estimating its impact on work efficiency. Means to improve accuracy in such estimations during planning are therefore important. In this paper, the influence of weather on a common construction method is studied. In short, temperature, wind speed, and precipitation are those variables that are reported to be most significant. Both cold and hot temperatures have a negative effect on productivity. Also machinery and material can be affected, especially by cold temperatures. High wind speeds and high precipitation also result in lower work efficiency. By importing climatic data with hourly resolution to a simulation model, the effect of weather could be simulated at a detailed level, which demonstrated how weather can be studied using a simulation-based approach enabling systematic analysis in a highly controlled way. Different scenarios were simulated including variations in weather conditions representative for Swedish climate (Stockholm), seasons for construction, and height of construction. It was found that construction is mostly affected by weather during winter season which is to be expected for a Nordic climate. Least effect on construction was during summer season. Extreme weather conditions were found to have both negative and positive impact, depending on season. Consequently, increased awareness and knowledge about weather conditions and seasonal variations become even more important in the future to account for climate change effects. The findings presented in this paper also address the need for planning construction related to different climatic zones and seasonal variations, both in Sweden but also on a global scale.

This paper contributes with knowledge of how weather affects construction and how it can be accounted for using simulations tools and climatic data with high resolution. The methodology is general and the influence of weather in other geographical regions than the one studied here can be analysed by adding other climatic data sets. Future research should focus on increasing the empirical base for developing relationships between weather variables and labor productivity. Developing relationships (or thresholds) which are specific for a certain work task (or group of work tasks) would make future estimations of weather even more precise. Future work should also focus on enhancing the capabilities of the simulation-based approach in order to account for 
weather in a more comprehensive way. For instance, including weather effects on other types of construction work tasks, equipment, and materials, such as concrete curing, etc.

\section{DATA AVAILABILITY STATEMENT}

Data generated or analyzed during the study are available from the corresponding author by request. Information about the Journal's data sharing policy can be found here: http://ascelibrary.org/doi/10.1061/\%28ASCE\%29CO.1943-7862.0001263.

\section{REFERENCES}

AbouRizk, S., Halpin, D., Mohamed, Y. and Hermann, U. (2011), "Research in Modeling and Simulation for Improving Construction Engineering Operations", Journal of Construction Engineering \& Management, Vol. 137, No. 10, pp. 843-852.

Andersson, Å (2017), Personal communication 2017-02-10. Crane operator, Peab (Swedish contractor), Malmö.

Ballesteros-Perez, P., del Campo-Hitschfeld, M.L., Gonzalez-Naranjo, M.A. and Gonzalez-Cruz, M.C. (2015), "Climate and construction delays: case study in Chile", Engineering, Construction and Architectural Management, Vol. 22, No. 6, pp. 596-621.

Birgisson, K.R. (2009), Discrete-event simulations of construction related production systems, Master Thesis, TVBK-5173, Lund University, Sweden.

Christian, J. and Hachey, D. (1995), "Effects of Delay Times on Production Rates in Construction", Journal of Construction Engineering \& Management, Vol. 121, No. 1, pp. 20.

Hassi, J. (2002), Handbok för kallt arbete, Arbetslivsinstitutet, pp. 112, ISBN: 9170456267, Stockholm, Sweden (in Swedish).

Holmér, I. (1994), "Cold stress: Part I - Guidelines for the practitioner", International Journal of Industrial Ergonomics, Vol. 14, No. 1-2, pp. 139-149.

Illingworth, J.R. (2000), Construction Methods and Planning, 2nd edition ed., translated by Anonymous Spon Press, London, U.K.

Jarkas, A. M. and Horner, R. M. W. (2015), "Creating a baseline for labour productivity of reinforced concre te building construction in Kuwait", Construction Management and Economics, Vol. 33, No. 8, pp. 625-6 39.

Jönsson, M. (2016), Personal communication 2016-10-31. Manager of crane rental services at Lambertsson (Swedish supplier of construction equipment), Malmö

Jung, M., Park, M., Lee, H. -S. and Kim, H. (2016), "Weather-delay simulation model based on vertical weat her profile for high-rise building construction", Journal of Construction Engineering and Management, V ol. 142, No. 6.

Koehn, E., Brown, G., Koehn, E. and Brown, G. (1985), "Climatic Effects on Construction", Journal of Construction Engineering and Management, Vol. 111, No. 2, pp. 129.

Krahl, D. (2003), "Extend: an interactive simulation tool", IEEE, New Orleans, LA., 7-10 december, pp. 188

Larsson, B. and Söderlind, L. (2006), Väderskyddad produktionsmiljö - Framtidens byggande; Sveriges Byggi ndustrier FoU-Väst (in Swedish).

Liebherr (2012), Influence of wind on crane operation, 3rd release ed., Liebherr-Werk Ehingen GmbH, Ehingen/Donau, Germany.

Lucko, G., Benjamin, P. C. and Madden, M. G. (2008), "Harnessing the power of simulation in the project man agement / decision support aspects of the construction industry", IEEE, Miami, FL, 7-10 december, $\mathrm{p}$ p. 2479. 
Mäkinen, T.M., Päkkönen, T., Rintamäki, H., Palinkas, L.A., Leppluoto, J. and Hassi, J. (2005), "Manual performance in urban circumpolar subjects exposed to cold in the winter and summer", Elsevier Ergonomics Book Series, Vol. 3, pp. 193-197.

Moselhi, O., Gong, D. and El-Rayes, K. (1997), "Estimating weather impact on the duration of construction activities", Canadian Journal of Civil Engineering, Vol. 24, No. 3, pp. 359-366.

Moselhi, O. and Khan, Z. (2010), "Analysis of labour productivity of formwork operations in building construction", Construction Innovation, Vol. 10, No. 3, pp. 286-303.

Moselhi, O. and Khan, Z. (2012), "Significance ranking of parameters impacting construction labour productivity", Construction Innovation (Emerald Group Publishing Limited), Vol. 12, No. 3, pp. 272.

Nguyen, L.D., Kneppers, J., Garca, d.S. and Ibbs, W. (2010), "Analysis of Adverse Weather for Excusable Delays", Journal of Construction Engineering \& Management, Vol. 136, No. 12, pp. 1258-1267.

Noreng, K. (2005), Verbeskyttet bygging med Weather Protection Systems (WPS) Byggforsk, Rapport 1192005, Oslo, Norway.

Sargent, R.G. (2013), "An introduction to verification and validation of simulation models", IEEE, Washington , DC., 8-11 december, pp. 321.

Schriber, T.J., Brunner, D.T. and Smith, J.S. (2013), "Inside discrete-event simulation software: how it works and why it matters", IEEE, Washington, DC., 8-11 december, pp. 424.

Şen, Z., Altunkaynak, A. and Erdik, T. (2012), "Wind Velocity Vertical Extrapolation by Extended Power Law", Advances in Meteorology, Vol. 2012, pp. 1-6.

Shahin, A., AbouRizk, S.M. and Mohamed, Y. (2011), "Modeling Weather-Sensitive Construction Activity Using Simulation", Journal of Construction Engineering \& Management, Vol. 137, No. 3, pp. 238-246.

Thomas, H. R. and Ellis Jr., R. D. (2009), "Fundamental principles of weather mitigation", Practice Periodi cal on Structural Design and Construction, Vol. 14, No. 1, pp. 29-35.

Thomas, H.R., Riley, D.R. and Sanvido, V.E. (1999), "Loss of labor productivity due to delivery methods and weather", Journal of Construction Engineering \& Management, Vol. 125, No. 1, pp. 39.

Thomas, H.R. and Yiakoumis, I. (1987), "Factor Model of Construction Productivity", Journal of Construction Engineering and Management, Vol. 113, No. 4, pp. 623.

Thomas, H.R. and Zavrski, I. (1999), "Construction baseline productivity: Theory and practice", Journal of Construction Engineering \& Management, Vol. 125, No. 5, pp. 295.

Watson, T. (2004), "When the wind blows”, World Market Intelligence. 
Table 1. Overview of references used in this paper to identify significant weather variables.

\begin{tabular}{|c|c|c|c|}
\hline Reference & Country & $\begin{array}{l}\text { Weather variables } \\
\text { in focus }\end{array}$ & Type of study \\
\hline $\begin{array}{l}\text { Koehn and Brown } \\
\text { (1985) }\end{array}$ & US & $\begin{array}{l}\text { Temperature, } \\
\text { humidity }\end{array}$ & $\begin{array}{l}\text { Review and analysis of historical } \\
\text { productivity data sets related to different } \\
\text { temperature and humidity intervals. }\end{array}$ \\
\hline $\begin{array}{l}\text { Thomas and } \\
\text { Yiakoumis (1987) }\end{array}$ & US & $\begin{array}{l}\text { Temperature, } \\
\text { humidity }\end{array}$ & $\begin{array}{l}\text { Measurements of productivity and weather } \\
\text { variables in three projects }\end{array}$ \\
\hline Holmér (1994) & Sweden & $\begin{array}{l}\text { Temperature, wind } \\
\text { speed (wind chill) }\end{array}$ & Measurements, experiments \\
\hline $\begin{array}{l}\text { Thomas et. al. } \\
\text { (1999) }\end{array}$ & US & $\begin{array}{l}\text { Temperature, } \\
\text { precipitation }\end{array}$ & $\begin{array}{l}\text { Measurements of productivity data and } \\
\text { weather variables }\end{array}$ \\
\hline Hassi (2002) & Sweden & Temperature & $\begin{array}{l}\text { Measurements and experiences (labor works, } \\
\text { not construction specific) }\end{array}$ \\
\hline Watson (2004) & UK & Wind speed & Based on industry experiences and expertise \\
\hline $\begin{array}{l}\text { Mäkinen et. al. } \\
(2005)\end{array}$ & Finland & Temperature & $\begin{array}{l}\text { Tests of manual performance (dexterity) } \\
\text { through controlled experiments }\end{array}$ \\
\hline Noreng (2005) & Norway & $\begin{array}{l}\text { Temperature, wind, } \\
\text { precipitation }\end{array}$ & $\begin{array}{l}\text { Assessments based on interviews and by } \\
\text { documentation of productivity and weather } \\
\text { variables in a number of construction } \\
\text { projects }\end{array}$ \\
\hline $\begin{array}{l}\text { Thomas and Ellis } \\
\text { (2009) }\end{array}$ & US & $\begin{array}{l}\text { Temperature, } \\
\text { precipitation }\end{array}$ & $\begin{array}{l}\text { Analysis of historical productivity data } \\
\text { related to weather variables }\end{array}$ \\
\hline Birgisson (2009) & Sweden & $\begin{array}{l}\text { Temperature, wind, } \\
\text { precipitation }\end{array}$ & $\begin{array}{l}\text { Assessments based on interviews with } \\
\text { industry practitioners }\end{array}$ \\
\hline $\begin{array}{l}\text { Mosehli and Kahn } \\
(2010)\end{array}$ & Canada & $\begin{array}{l}\text { Temperature, wind, } \\
\text { precipitation }\end{array}$ & $\begin{array}{l}\text { Measurements of productivity and weather } \\
\text { variables }\end{array}$ \\
\hline Shahin (2011) & Canada & $\begin{array}{l}\text { Temperature, wind, } \\
\text { precipitation, frost } \\
\text { depth }\end{array}$ & $\begin{array}{l}\text { Assessments based on interviews with } \\
\text { industry experts }\end{array}$ \\
\hline $\begin{array}{l}\text { Ballesteros-Perez et. } \\
\text { al. (2015) }\end{array}$ & Chile & $\begin{array}{l}\text { Temperature, wind, } \\
\text { precipitation }\end{array}$ & $\begin{array}{l}\text { Assessments based on previous research and } \\
\text { industry expert's judgements }\end{array}$ \\
\hline Jung et. al. (2016) & $\begin{array}{l}\text { South } \\
\text { Korea }\end{array}$ & $\begin{array}{l}\text { Temperature, wind, } \\
\text { precipitation } \\
\text { (stoppage criteria) }\end{array}$ & Interviews with site managers \\
\hline
\end{tabular}


Table 2. Summary of documented effects of weather on construction productivity.

\begin{tabular}{|c|c|c|c|}
\hline $\begin{array}{l}\text { Weather } \\
\text { parameter }\end{array}$ & $\begin{array}{l}\text { Type of work } \\
\text { affected }\end{array}$ & Influence on activity & Remark \\
\hline Temperature & $\begin{array}{l}\text { Most type of } \\
\text { works involving } \\
\text { individuals }\end{array}$ & $\begin{array}{l}\text { Reduced productivity at cold } \\
\text { and hot temperatures. Examples } \\
\text { of relationships are given in } \\
\text { Figure } 3 .\end{array}$ & $\begin{array}{l}\text { Curing of concrete is affected by temperature } \\
\text { which determine the time when formwork } \\
\text { can be removed. Also, equipment and } \\
\text { machines may be affected by extreme } \\
\text { temperatures. }\end{array}$ \\
\hline Rain & $\begin{array}{l}\text { Most type of } \\
\text { works involving } \\
\text { individuals }\end{array}$ & $\begin{array}{l}\text { Labor productivity is reduced } \\
\text { already at light rain. } \\
\text { Light rain (above } 0,2 \mathrm{~mm} / \mathrm{h} \text { ): } \\
40 \% \text { loss. } \\
\text { Rain above } 0,5 \mathrm{~mm} / \mathrm{h}: 50-65 \% \\
\text { loss. }\end{array}$ & $\begin{array}{l}\text { Pouring concrete slab is sensitive to heavy } \\
\text { rainfall. Pouring may have to be cancelled or } \\
\text { measures to protect the surface have to be } \\
\text { carried out. Materials have to be protected } \\
\text { from rain. }\end{array}$ \\
\hline Snow & $\begin{array}{l}\text { Most type of } \\
\text { works involving } \\
\text { individuals }\end{array}$ & $\begin{array}{l}\text { Labor productivity is also } \\
\text { reduced during snowfall. } \\
\text { The effect varies between } 10- \\
60 \% \text { loss due to intensity. }\end{array}$ & $\begin{array}{l}\text { Works on concrete slabs are more sensitive } \\
\text { to snowfall than walls. Actions to protect a } \\
\text { working area must be carried out if snowfall } \\
\text { is expected. Materials have to be protected } \\
\text { from rain. }\end{array}$ \\
\hline Wind & $\begin{array}{l}\text { Work at heights, } \\
\text { Lifting } \\
\text { operations (e.g. } \\
\text { formwork). }\end{array}$ & $\begin{array}{l}\text { Lifting operations cancelled at } \\
\text { wind speeds }>20 \mathrm{~m} / \mathrm{s} \\
\text { About } 20 \% \text { productivity loss at } \\
\text { wind speeds in the range of } 10- \\
12 \mathrm{~m} / \mathrm{s} \text {. Above these wind } \\
\text { speeds, the loss in productivity } \\
\text { increases rapidly as discussed in } \\
\text { (Moselhi and Khan 2010). }\end{array}$ & $\begin{array}{l}\text { Thresholds for cancelling formwork and } \\
\text { concrete operations may vary. For instance, } \\
\text { in Sweden formwork operations and pouring } \\
\text { concrete are normally avoided at wind } \\
\text { speeds above } 15 \mathrm{~m} / \mathrm{s} \\
\text { Additional safety measures may be required } \\
\text { at high winds. }\end{array}$ \\
\hline
\end{tabular}

Table 3. Description of field study projects and data collection activities.

\begin{tabular}{|l|l|l|l|l|}
\hline $\begin{array}{l}\text { Field } \\
\text { study }\end{array}$ & Project type & $\begin{array}{l}\text { Building } \\
\text { characteristics }\end{array}$ & $\begin{array}{l}\text { Construction } \\
\text { method }\end{array}$ & Field study activities \\
\hline A & $\begin{array}{l}\text { Multifamily } \\
\text { building }\end{array}$ & $\begin{array}{l}\text { Two buildings } \\
\text { Six floors } \\
74 \text { apartments }\end{array}$ & $\begin{array}{l}\text { In-situ concrete } \\
\text { Modular } \\
\text { formwork }\end{array}$ & $\begin{array}{l}\text { Process documentation (work sequence, } \\
\text { resource usage) } \\
\text { Interviews with site personnel and suppliers } \\
\text { (work practice, activity durations) } \\
\text { On-site observations }\end{array}$ \\
\hline B & $\begin{array}{l}\text { Multifamily } \\
\text { building }\end{array}$ & $\begin{array}{l}\text { One building } \\
\text { Four floors } \\
126 \text { apartments }\end{array}$ & $\begin{array}{l}\text { In-situ concrete } \\
\text { Modular } \\
\text { formwork }\end{array}$ & $\begin{array}{l}\text { Process documentation (work sequence, } \\
\text { resource usage) } \\
\text { Time studies (productivity data) }\end{array}$ \\
\hline
\end{tabular}


Table 4. Summary of baseline productivity data for concrete wall activities.

\begin{tabular}{|l|l|l|}
\hline $\begin{array}{l}\text { Activity } \\
\text { (according to Figure 6) }\end{array}$ & Unit & $\begin{array}{l}\text { Baseline (man-hours/unit) } \\
\text { Size of baseline subset }=5\end{array}$ \\
\hline 1. Erect formwork 1st side & $\mathrm{m}^{2}$ & 0,1 \\
\hline 2. Box outs & $\mathrm{pcs}$ & 0,3 \\
\hline 3. Place MEP & $\mathrm{m}^{2}$ & 0,02 \\
\hline 4. Fix rebars & $\mathrm{kg}$ & 0,01 \\
\hline 5. Erect formwork 2nd side & $\mathrm{m}^{2}$ & 0,06 \\
\hline 6. Pour concrete & $\mathrm{m}^{3}$ & 0,22 \\
\hline 7. Curing & $\mathrm{hrs}^{*}$ & $15^{*}$ \\
\hline 8. Strip formwork & $\mathrm{m}^{2}$ & 0,02 \\
\hline 9. Move/relocate formwork & $\mathrm{m}^{2}$ & 0,02 \\
\hline
\end{tabular}

*) Refers to the time necessary for concrete to reach 6MPa in compression strength which is a recommended threshold in Sweden for removing wall formwork.

Table 5. Overview of variables included in the simulation experiments.

\begin{tabular}{|l|l|l|l|l|l|}
\hline $\begin{array}{l}\text { Weather } \\
\text { condition }\end{array}$ & Year & $\begin{array}{l}\text { Effect of } \\
\text { Temp }\end{array}$ & $\begin{array}{l}\text { Effect of } \\
\text { wind }\end{array}$ & $\begin{array}{l}\text { Effect of } \\
\text { prec. }\end{array}$ & $\begin{array}{l}\text { Combined effects } \\
\text { temp+wind+prec.) }\end{array}$ \\
\hline Normal & 1997 & $\begin{array}{l}\text { Win/Spr/ } \\
\text { Sum/Aut }\end{array}$ & $\begin{array}{l}\text { Win/Spr/ } \\
\text { Sum/Aut }\end{array}$ & $\begin{array}{l}\text { Win/Spr/ } \\
\text { Sum/Aut }\end{array}$ & Win/Spr/Sum/Aut \\
\hline HighTemp & 2014 & $\begin{array}{l}\text { Win/Spr/ } \\
\text { Sum/Aut }\end{array}$ & $\begin{array}{l}\text { Win/Spr/ } \\
\text { Sum/Aut }\end{array}$ & $\begin{array}{l}\text { Win/Spr/ } \\
\text { Sum/Aut }\end{array}$ & Win/Spr/Sum/Aut \\
\hline LowTemp & 2010 & $\begin{array}{l}\text { Win/Spr/ } \\
\text { Sum/Aut }\end{array}$ & $\begin{array}{l}\text { Win/Spr/ } \\
\text { Sum/Aut }\end{array}$ & $\begin{array}{l}\text { Win/Spr/ } \\
\text { Sum/Aut }\end{array}$ & Win/Spr/Sum/Aut \\
\hline Windy & 2011 & $\begin{array}{l}\text { Win/Spr/ } \\
\text { Sum/Aut }\end{array}$ & $\begin{array}{l}\text { Win/Spr/ } \\
\text { Sum/Aut }\end{array}$ & $\begin{array}{l}\text { Win/Spr/ } \\
\text { Sum/Aut }\end{array}$ & Win/Spr/Sum/Aut \\
\hline HighPrec. & 2012 & $\begin{array}{l}\text { Win/Spr/ } \\
\text { Sum/Aut }\end{array}$ & $\begin{array}{l}\text { Win/Spr/ } \\
\text { Sum/Aut }\end{array}$ & $\begin{array}{l}\text { Win/Spr/ } \\
\text { Sum/Aut }\end{array}$ & Win/Spr/Sum/Aut \\
\hline
\end{tabular}

Table 6.Summary of weather-productivity relationships and thresholds for work stoppages incorporated into the simulation model.

\begin{tabular}{|c|c|c|c|}
\hline Activity & Temperature ( $\left.\mathrm{p}_{\text {temp }}\right)$ & $\begin{array}{l}\text { Rainfall/snowfall } \\
\left(\mathrm{p}_{\text {prec }}\right)\end{array}$ & Wind speed $\left(\mathrm{p}_{\text {wind }}\right)$ \\
\hline 1. Erect formwork (1 ${ }^{\text {st }}$ side) & $\begin{array}{l}\text { According to Figure } 3 \\
\text { (Mosehli and Kahn) }\end{array}$ & $\begin{array}{l}\text { According to } \\
\text { Figure } 4\end{array}$ & $\begin{array}{l}\mathrm{W}>15 \mathrm{~m} / \mathrm{s}^{*} \text { : Lifting is cancelled } \\
\mathrm{W}<15 \mathrm{~m} / \mathrm{s} \text { : According to Figure } 5\end{array}$ \\
\hline 2. Box outs/openings & $\begin{array}{l}\text { According to Figure } 3 \\
\text { (Mosehli and Kahn) }\end{array}$ & $\begin{array}{l}\text { According to } \\
\text { Figure } 4\end{array}$ & $\mathrm{~W}>20 \mathrm{~m} / \mathrm{s}$ : Lifting is cancelled \\
\hline 3. Place MEP & $\begin{array}{l}\text { According to Figure } 3 \\
\text { (Mosehli and Kahn) }\end{array}$ & $\begin{array}{l}\text { According to } \\
\text { Figure } 4\end{array}$ & $\mathrm{~W}>20 \mathrm{~m} / \mathrm{s}$ : Lifting is cancelled \\
\hline 4. Erect formwork ( $2^{\text {nd }}$ side $)$ & $\begin{array}{l}\text { According to Figure } 3 \\
\text { (Mosehli and Kahn) }\end{array}$ & $\begin{array}{l}\text { According to } \\
\text { Figure } 4\end{array}$ & $\begin{array}{l}\mathrm{W}>15 \mathrm{~m} / \mathrm{s}^{*}: \text { Lifting is cancelled } \\
\mathrm{W}<15 \mathrm{~m} / \mathrm{s} \text { : According to Figure } 5\end{array}$ \\
\hline 5. Fix rebars & $\begin{array}{l}\text { According to Figure } 3 \\
\text { (Mosehli and Kahn) }\end{array}$ & \begin{tabular}{|l|} 
According to \\
Figure 4 \\
\end{tabular} & $\mathrm{~W}>20 \mathrm{~m} / \mathrm{s}$ : Lifting is cancelled \\
\hline 6. Pour concrete & $\begin{array}{l}\text { According to Figure } 3 \\
\text { (Mosehli and Kahn) }\end{array}$ & $\begin{array}{l}\text { According to } \\
\text { Figure } 4\end{array}$ & $\mathrm{~W}>15 \mathrm{~m} / \mathrm{s}$ : Lifting is cancelled \\
\hline 7. Curing concrete & $\mathrm{n} / \mathrm{a}$ & $\mathrm{n} / \mathrm{a}$ & $\mathrm{n} / \mathrm{a}$ \\
\hline 8. Strip formwork & $\begin{array}{l}\text { According to Figure } 3 \\
\text { (Mosehli and Kahn) }\end{array}$ & $\begin{array}{l}\text { According to } \\
\text { Figure } 4\end{array}$ & $\begin{array}{l}\mathrm{W}>15 \mathrm{~m} / \mathrm{s}^{*} \text { : Lifting is cancelled } \\
\mathrm{W}<15 \mathrm{~m} / \mathrm{s} \text { : According to Figure } 5\end{array}$ \\
\hline $\begin{array}{l}\text { 9. Move Formwork to next } \\
\text { location }\end{array}$ & $\begin{array}{l}\text { According to Figure } 3 \\
\text { (Mosehli and Kahn) }\end{array}$ & $\begin{array}{l}\text { According to } \\
\text { Figure } 4\end{array}$ & $\begin{array}{l}\mathrm{W}>15 \mathrm{~m} / \mathrm{s}^{*}: \text { Lifting is cancelled } \\
\mathrm{W}<15 \mathrm{~m} / \mathrm{s}: \text { According to Figure } 5\end{array}$ \\
\hline
\end{tabular}


Table 7. Sample of model input data used for simulation experiments.

\begin{tabular}{|l|l|l|l|l|l|l|l|l|l|l|l|l|l|l|}
\hline $\begin{array}{l}\text { Row } \\
\text { no }\end{array}$ & $\begin{array}{l}\text { Build. } \\
\text { ID }\end{array}$ & $\begin{array}{l}\text { Floor } \\
\text { level }\end{array}$ & $\begin{array}{l}\text { Height } \\
(\mathrm{m})^{1}\end{array}$ & $\begin{array}{l}\text { Wall } \\
\text { Phase }\end{array}$ & $\begin{array}{l}\text { Wall } \\
\text { No }\end{array}$ & $\begin{array}{l}\text { Wall } \\
\text { area } \\
(\mathrm{m} 2)\end{array}$ & $\begin{array}{l}\text { Concrete } \\
\text { volume } \\
(\mathrm{m} 3)\end{array}$ & $\begin{array}{l}\text { Rebars } \\
(\mathrm{kg})\end{array}$ & $\begin{array}{l}\text { Box } \\
\text { outs } \\
(\mathrm{pcs})\end{array}$ & $\begin{array}{l}\text { MEP } \\
(\text { Y/N) }\end{array}$ & \multicolumn{3}{|c|}{ Formwork $^{2}$ usage strategy } \\
\hline $\begin{array}{l}\text { TRH } \\
540\end{array}$ & $\begin{array}{l}\text { TRH- } \\
360\end{array}$ & $\begin{array}{l}\text { TRH } \\
-270\end{array}$ & $\begin{array}{l}\text { TRH- } \\
180\end{array}$ \\
\hline 1 & 1 & 1 & 12 & 1 & 1 & 5,2 & 0,9 & 52 & 0 & Yes & 0 & 1 & 0 & 0 \\
\hline 2 & 1 & 1 & 12 & 1 & 2 & 13,3 & 2,9 & 133 & 0 & Yes & 1 & 0 & 0 & 0 \\
\hline 3 & 1 & 1 & 12 & 1 & 3 & 13,3 & 2,9 & 133 & 0 & Yes & 1 & 0 & 0 & 0 \\
\hline 4 & 1 & 1 & 12 & 1 & 4 & 5,5 & 1,2 & 55 & 0 & Yes & 0 & 0 & 1 \\
\hline 5 & 1 & 1 & 12 & 1 & 5 & 5,5 & 1,2 & 55 & 0 & Yes & 0 & 0 & 1 \\
\hline 6 & 1 & 1 & 12 & 1 & 6 & 13,8 & 3 & 138 & 0 & Yes & 1 & 0 & 0 \\
\hline 7 & 1 & 1 & 12 & 1 & 7 & 6,8 & 1,5 & 68 & 0 & Yes & 0 & 0 & 0 \\
\hline$\ldots$ & $\ldots$ & $\ldots$ & $\ldots$ & $\ldots$ & $\ldots$ & $\ldots$ & $\ldots$ & $\ldots$ & $\ldots$ & $\ldots$ & $\ldots$ & $\ldots$ & $\ldots$ \\
\hline 134 & 1 & 6 & 32 & 4 & 1 & 6,0 & 1,3 & 60 & 0 & Yes & 0 & 0 & 1 \\
\hline 135 & 1 & 6 & 32 & 4 & 2 & 5,2 & 1,1 & 52 & 0 & Yes & 0 & 0 & 0 \\
\hline 136 & 1 & 6 & 32 & 4 & 3 & 5,2 & 1,1 & 52 & 0 & Yes & 0 & 0 & 0 \\
\hline 137 & 1 & 6 & 32 & 4 & 4 & 6,8 & 1,5 & 68 & 0 & Yes & 0 & 1 & 0 \\
\hline 138 & 1 & 6 & 32 & 4 & 5 & 10,1 & 1,8 & 101 & 1 & Yes & 1 & 0 & 0 \\
\hline
\end{tabular}

796

797

798

799

800

801

802

803

${ }^{1}$ Relates to maximum height of lifting position. Calculated as follows: ((Floor level-1) x $\left.4 \mathrm{~m}\right)+12 \mathrm{~m}$. For visual reasons, highest lifting position should be $12 \mathrm{~m}$ above highest point of building.

${ }^{2}$ Concerns different formwork types, e.g. TRH-540.

Table 8. Resource allocation plan for concrete wall construction activities.

\begin{tabular}{|l|l|l|l|l|}
\hline \multirow{2}{*}{ Activity } & \multicolumn{4}{|c|}{ Resource allocation plan } \\
\cline { 2 - 5 } & Carpenters & Concreters & $\begin{array}{l}\text { Sub- } \\
\text { contractors }\end{array}$ & Crane \\
\hline 1.Erect formwork (1st side) & 3 & 2 & 0 & 1 \\
\hline 2. Box outs & 3 & 0 & 0 & 0 \\
\hline 3.Place MEP & 0 & 0 & 1 & 0 \\
\hline 4. Fix rebars & 1 & 2 & 0 & 0 \\
\hline 5.Erect formwork (2nd side) & 3 & 2 & 0 & 1 \\
\hline 6.Pour concrete & 0 & 2 & 0 & 1 \\
\hline 7. Curing & $\mathrm{n} / \mathrm{a}$ & $\mathrm{n} / \mathrm{a}$ & $\mathrm{n} / \mathrm{a}$ & $\mathrm{n} / \mathrm{a}$ \\
\hline 8.Strip formwork & 3 & 2 & 0 & 1 \\
\hline 9.Move formwork & 3 & 0 & 0 & 1 \\
\hline
\end{tabular}




\section{List of figure captions}

\section{Manuscript ID: COENG-7431}

Title: Studying the impact of weather conditions on in-situ concrete wall operations using a simulation based approach

Figure 1. A schematic illustration of the overall research process.

Figure 2. Illustration of baseline productivity versus actual productivity as a function of work complexity, revised from Thomas and Zavrski (1999).

Figure 3. Relation between temperature and productivity loss based on (Moselhi and Khan 2010, Koehn and Brown 1985, Hassi 2002).

Figure 4. Influence of precipitation on construction efficiency based on previous studies.

Figure 5. Influence of wind speed on construction works based on Moselhi and Kahn (2010) and threshold for recommended and maximum allowable wind speeds.

Figure 6. Flowchart of construction sequence of concrete walls found in field projects.

Figure 7. Floor plan layout and construction sequence of walls including formwork usage scheme of the two buildings in field project $A$.

Figure 8. Example of data productivity sampling protocol and productivity observations used to determine baseline productivity for pouring concrete walls.

Figure 9. Illustration of simulation model and its components including data management.

Figure 10. Flowchart describing how weather is accounted for in the simulation model.

Figure 11. Hourly wind speed variation versus average wind speed.

Figure 12. Simulated weather effects on project duration relative the baseline scenario (no impact from weather effects).

Figure 13. Simulated effects of building height and allowable wind speeds for formwork relative a baseline scenario (no weather effects) for normal weather conditions. 


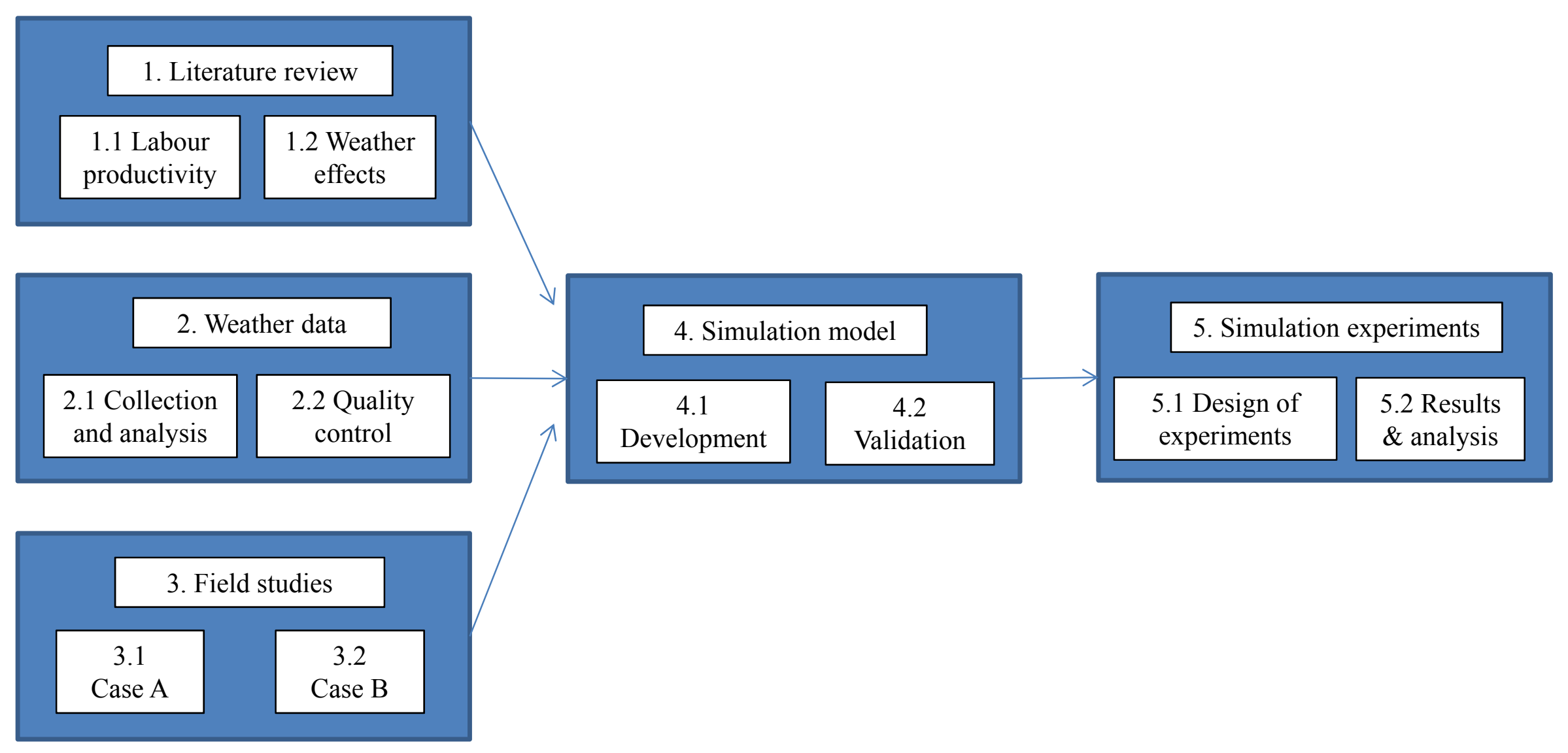




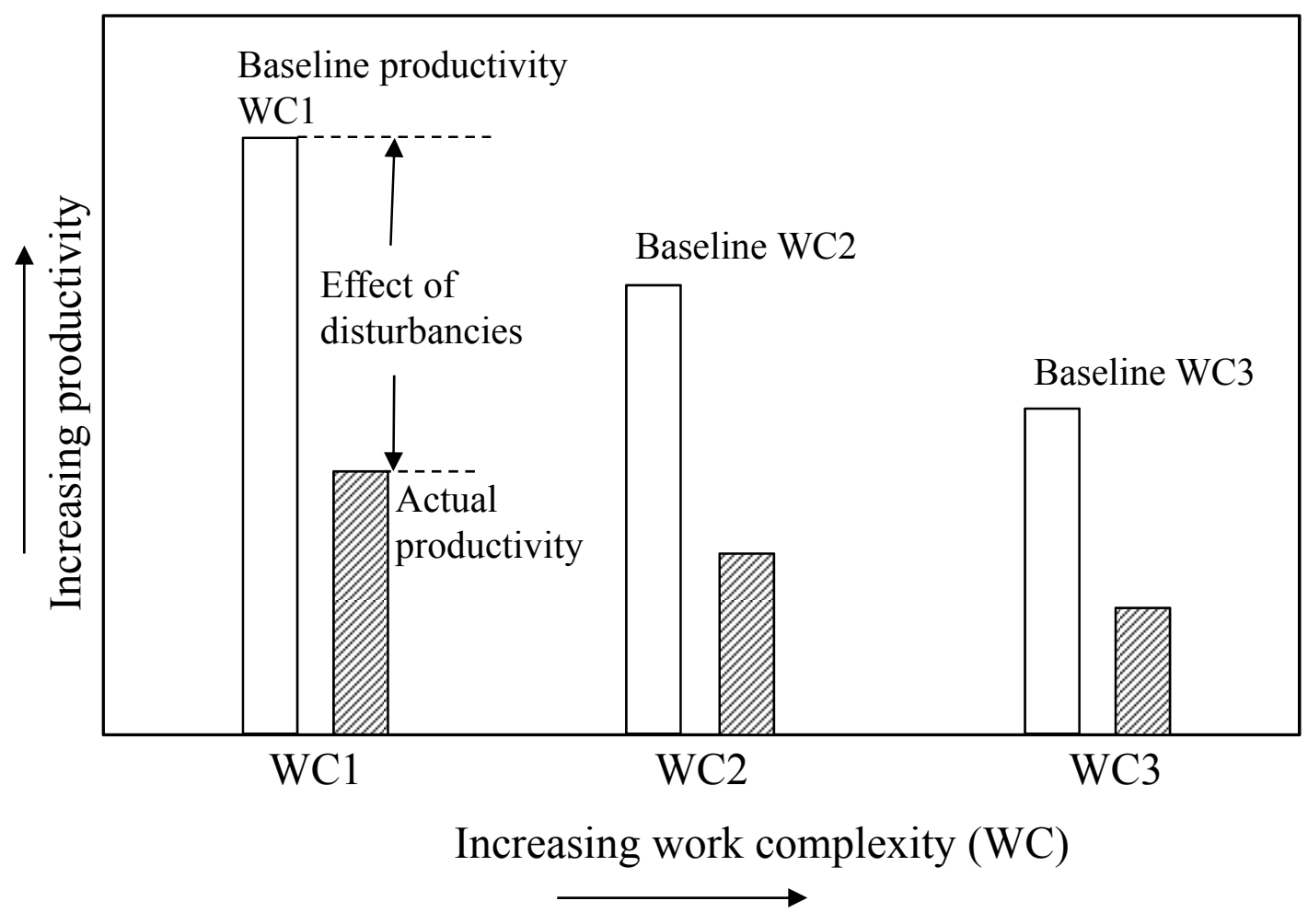




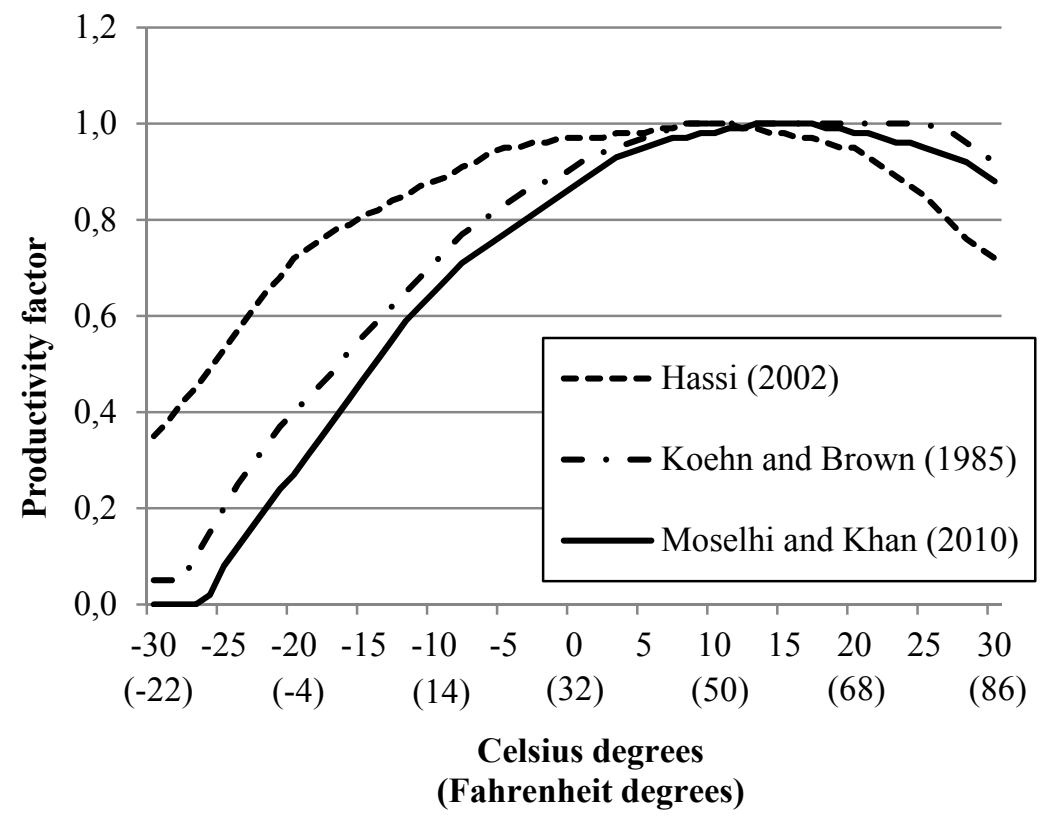




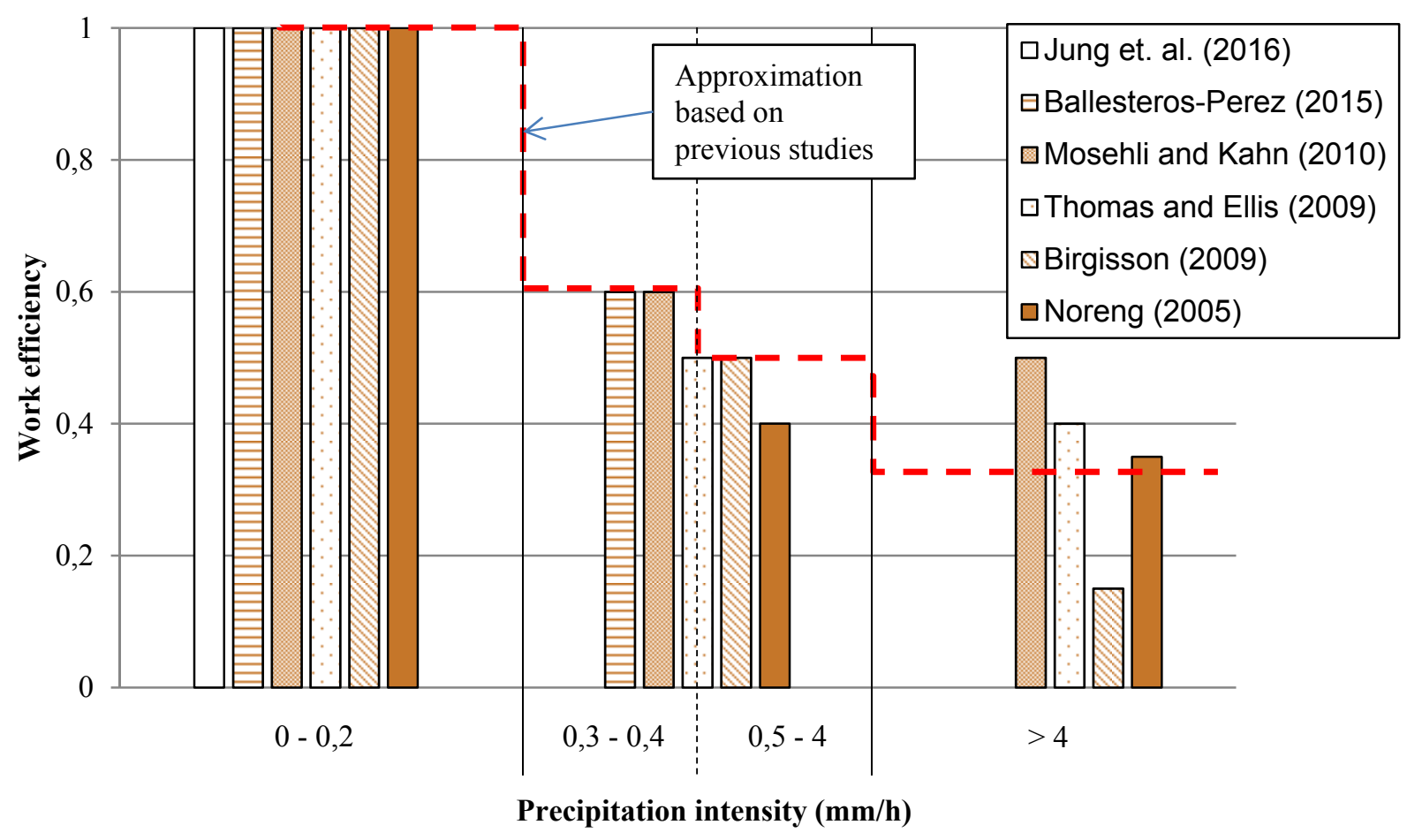




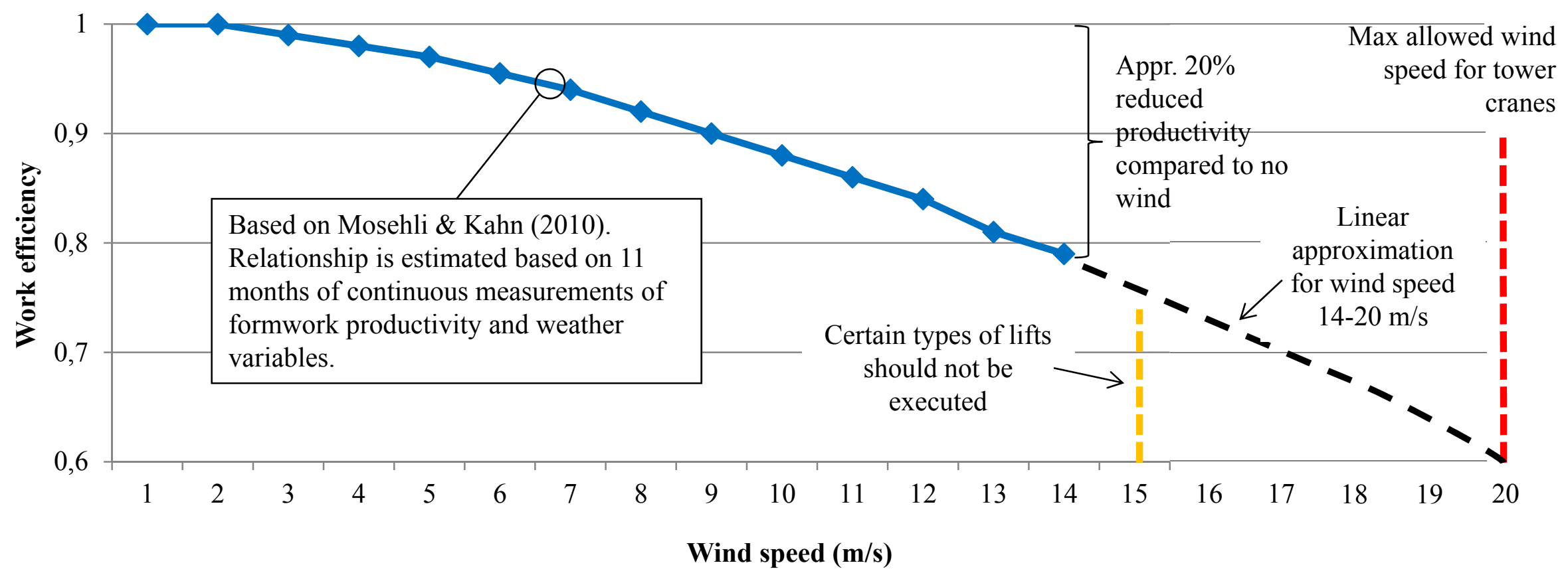




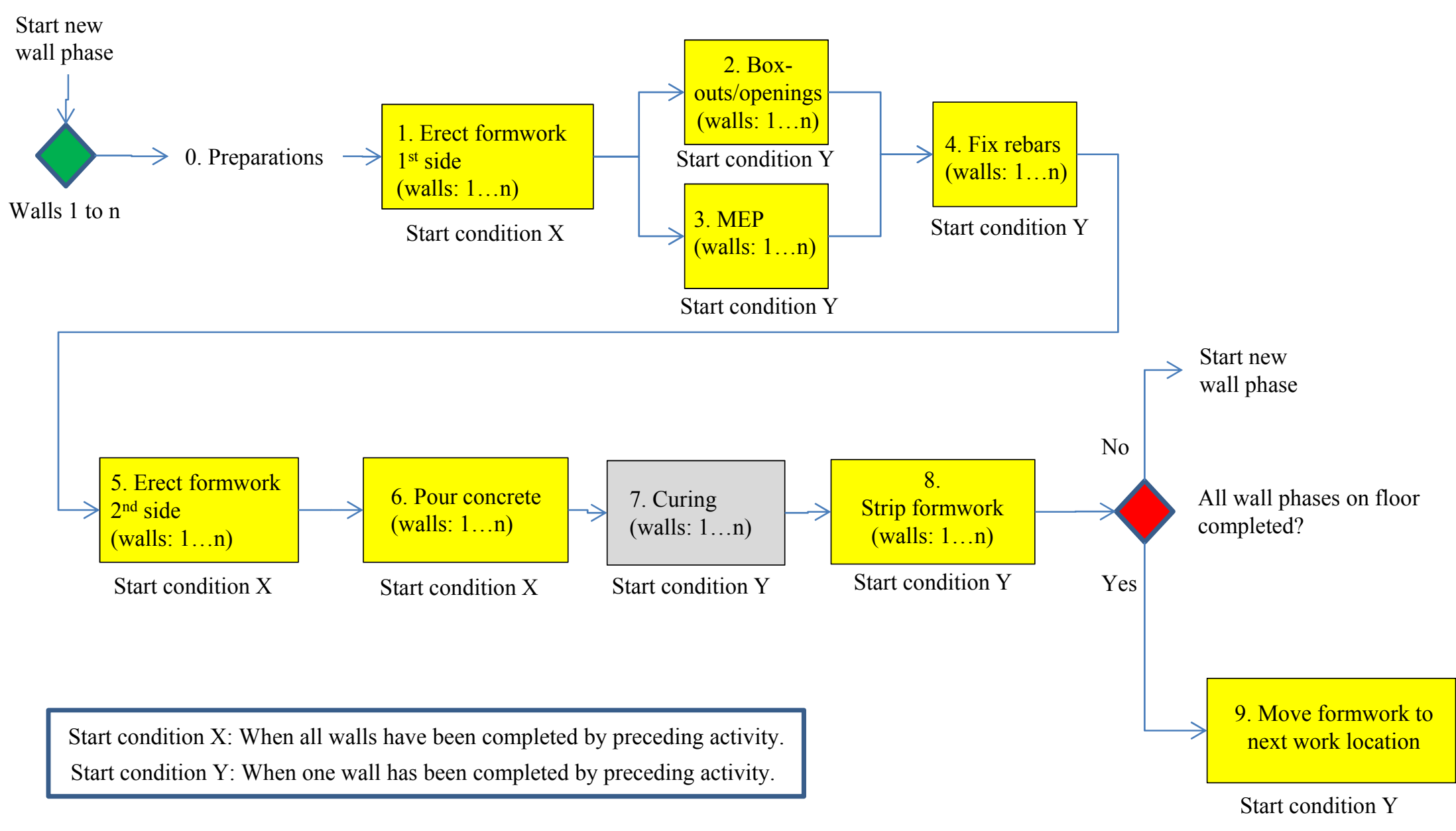


Building 1

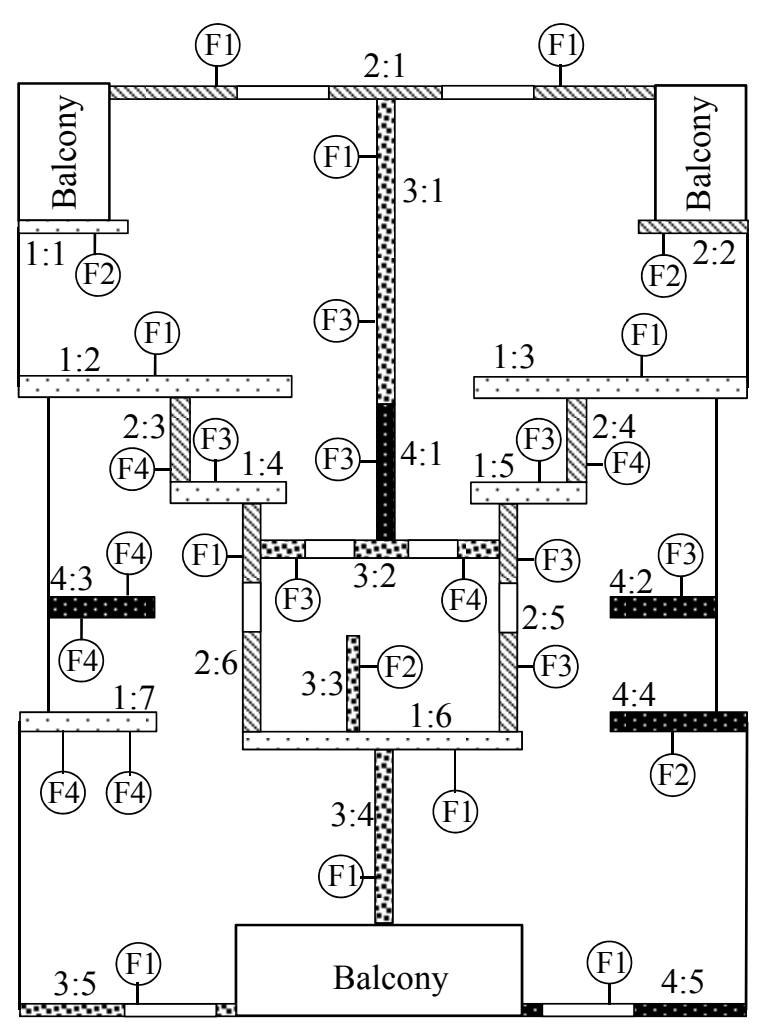

[2:3] $=$ Wall phase 2:Wall number 3

(F1) Formwork panel type F1
Building 2

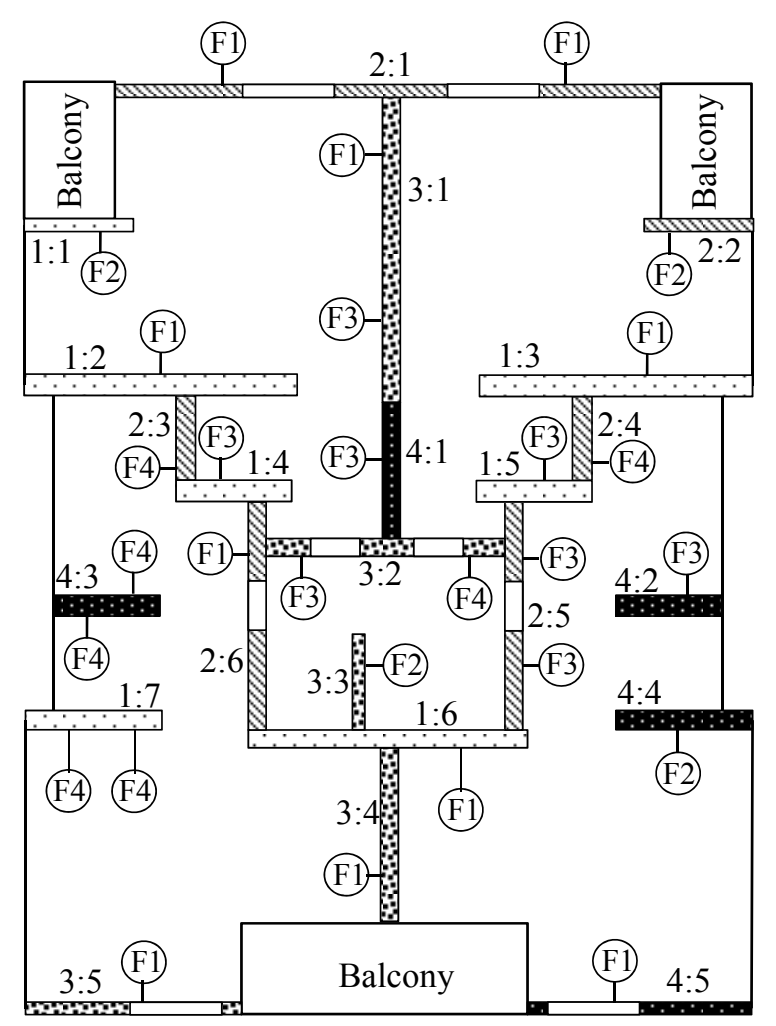




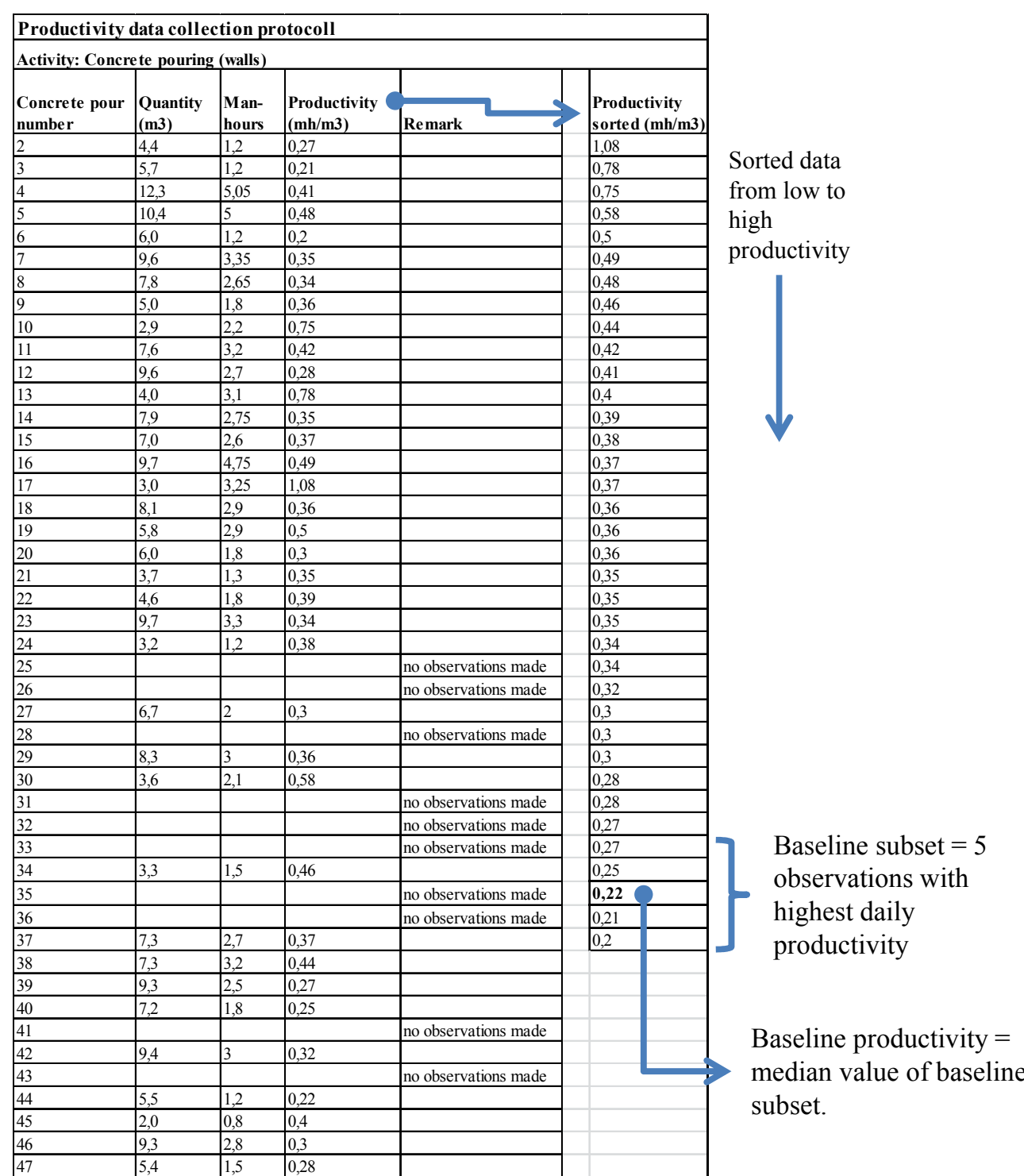




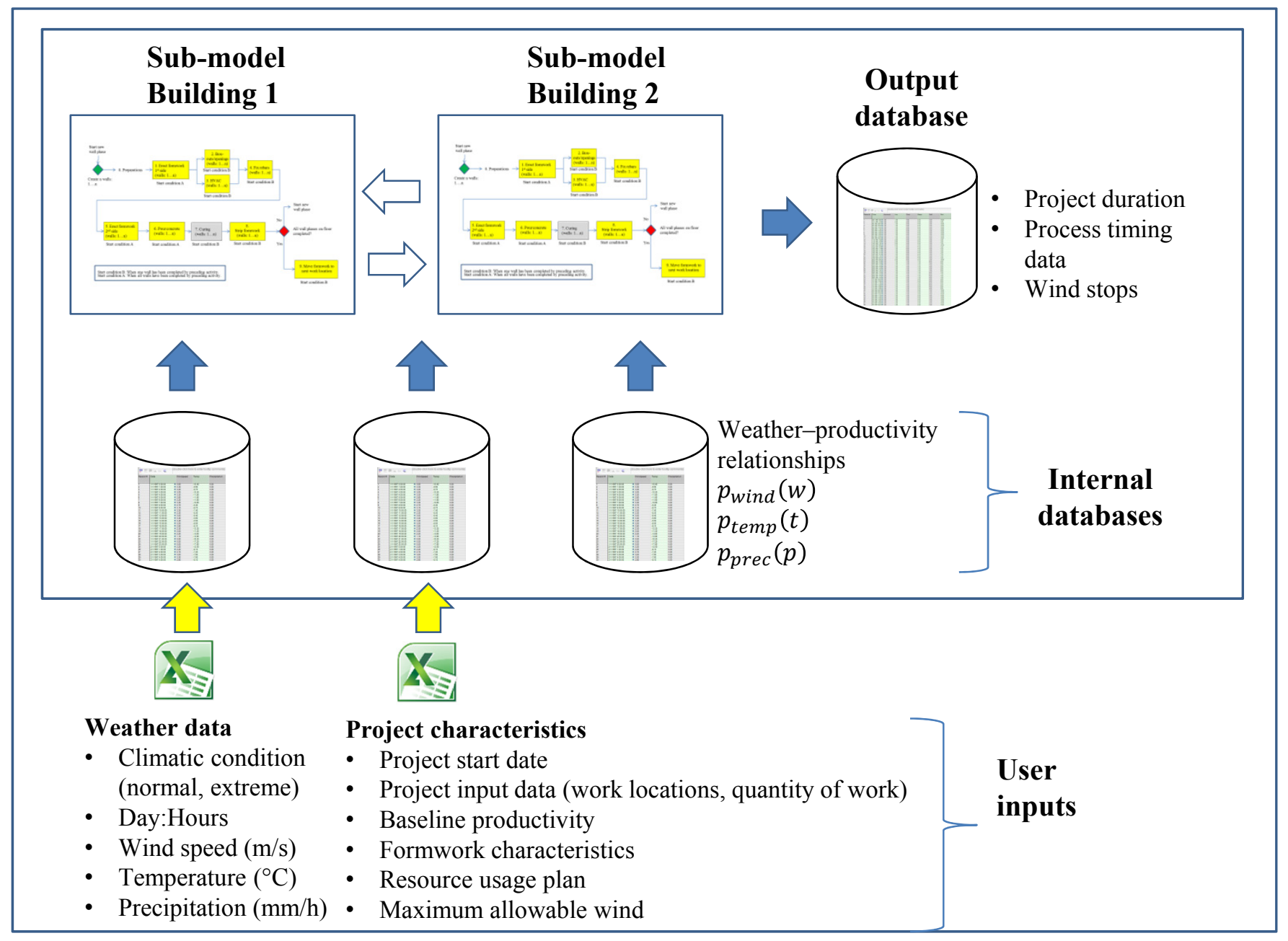




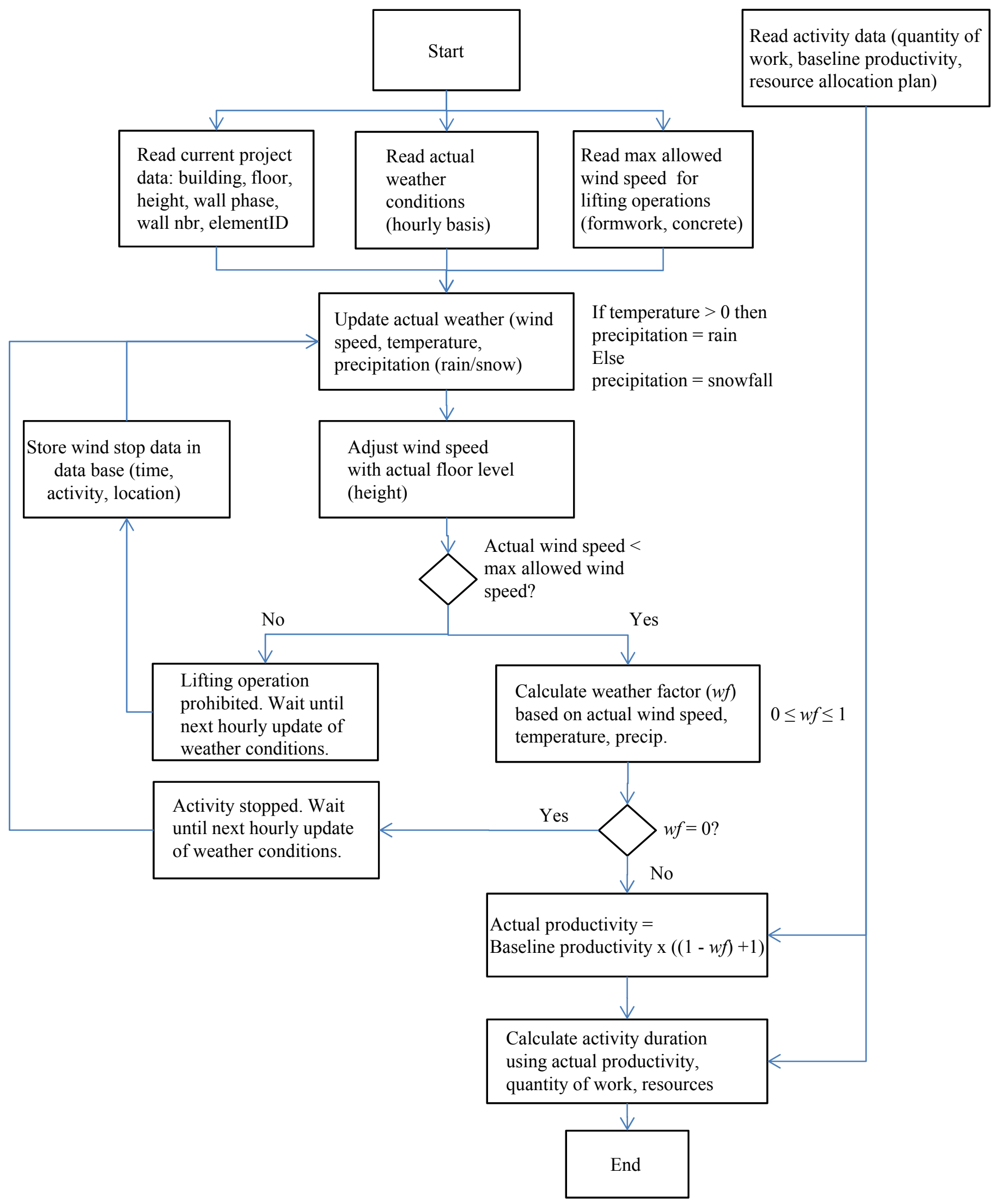




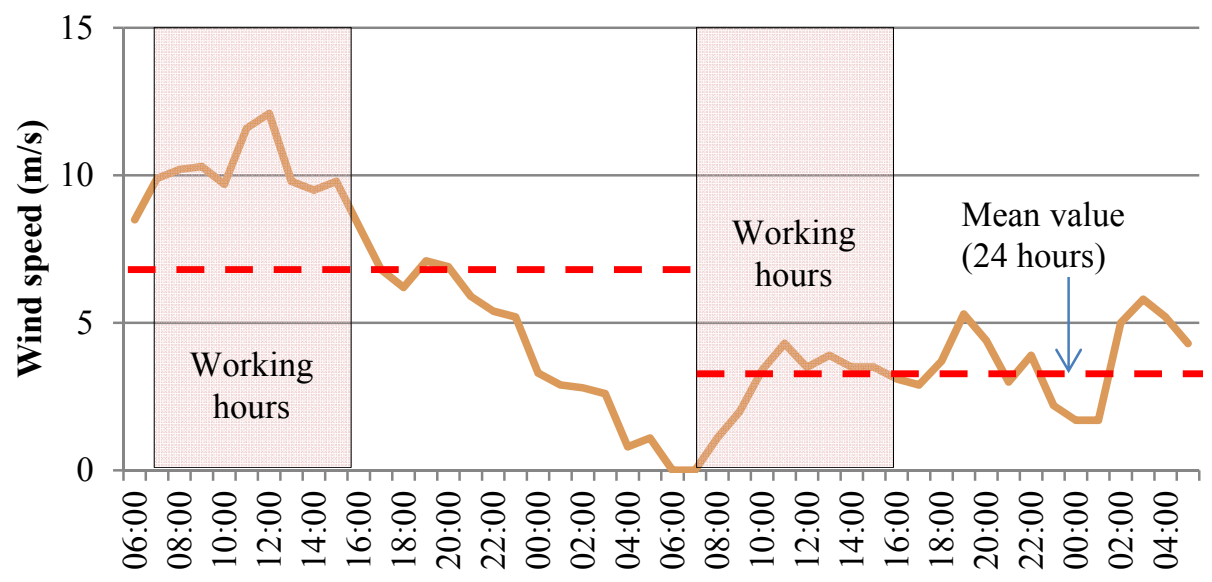




\begin{tabular}{|c|c|c|c|c|c|c|c|c|c|c|c|c|c|c|c|c|}
\hline \multirow[t]{2}{*}{$\begin{array}{l}\text { Weather } \\
\text { condition }\end{array}$} & \multicolumn{4}{|c|}{ Effect of temp } & \multicolumn{4}{|c|}{ Effect of wind } & \multicolumn{4}{|c|}{ Effect of precipitation } & \multicolumn{4}{|c|}{$\begin{array}{l}\text { Combined effect of } \\
\text { temp, wind, } \\
\text { precipitation }\end{array}$} \\
\hline & Win & Spr & Sum & Aut & Win & Spr & Sum & Aut & Win & Spr & Sum & Aut & Win & $\mathrm{Spr}$ & Sum & $\mathrm{Au}$ \\
\hline Baseline & 1,00 & 1,00 & 1,00 & 1,00 & 1,00 & 1,00 & 1,00 & 1,00 & 1,00 & 1,00 & 1,00 & 1,00 & 1,00 & 1,00 & 1,00 & 1,00 \\
\hline Normal & 1,35 & 1,10 & 1,12 & 1,17 & 1,10 & 1,14 & 1,02 & 1,08 & 1,00 & 1,04 & 1,02 & 1,02 & 1,46 & 1,25 & 1,14 & 1,29 \\
\hline HighTemp & 1,33 & 1,08 & 1,10 & 1,08 & 1,06 & 1,06 & 1,08 & 1,06 & 1,04 & 1,06 & 1,04 & 1,08 & 1,39 & 1,19 & 1,17 & 1,14 \\
\hline LowTemp & 1,60 & 1,06 & 1,06 & 1,14 & 1,00 & 1,08 & 1,08 & 1,08 & 1,02 & 1,04 & 1,06 & 1,12 & 1,60 & 1,14 & 1,17 & 1,37 \\
\hline Windy & 1,50 & 1,00 & 1,06 & 1,08 & 1,08 & 1,10 & 1,06 & 1,02 & 1,06 & 1,02 & 1,10 & 1,04 & 1,54 & 1,17 & 1,14 & 1,21 \\
\hline HighPrec. & 1,41 & 1,04 & 1,00 & 1,14 & 1,04 & 1,06 & 1,08 & 1,02 & 1,06 & 1,10 & 1,06 & 1,04 & 1,52 & 1,25 & 1,12 & 1,21 \\
\hline
\end{tabular}




\begin{tabular}{|c|c|c|c|c|c|c|c|c|}
\hline \multirow[b]{2}{*}{$\begin{array}{l}\text { Simulation scenarios } \\
\text { (normal weather) }\end{array}$} & \multicolumn{2}{|c|}{ Winter } & \multicolumn{2}{|c|}{ Spring } & \multicolumn{2}{|c|}{ Summer } & \multicolumn{2}{|c|}{ Autumn } \\
\hline & $\begin{array}{c}\text { Impact on } \\
\text { duration }\end{array}$ & $\begin{array}{c}\text { Wind stop } \\
\text { (days) }\end{array}$ & $\begin{array}{c}\text { Impact on } \\
\text { duration }\end{array}$ & $\begin{array}{c}\text { Wind stop } \\
\text { (days) }\end{array}$ & $\begin{array}{c}\text { Impact on } \\
\text { duration }\end{array}$ & $\begin{array}{c}\text { Wind stop } \\
\text { (days) }\end{array} \mid$ & $\begin{array}{l}\text { Impact on } \\
\text { duration }\end{array}$ & \begin{tabular}{|l} 
Wind \\
stop \\
(days)
\end{tabular} \\
\hline Baseline: 6 floors $(20 \mathrm{~m} / \mathrm{s})$ & $\pm 0 \%$ & 0 & $\pm 0 \%$ & 0 & $\pm 0 \%$ & 0 & $\pm 0 \%$ & 0 \\
\hline $\begin{array}{l}6 \text { floors, Formwork } 15 \mathrm{~m} / \mathrm{s}, \\
\text { concrete } 15 \mathrm{~m} / \mathrm{s}\end{array}$ & $+10 \%$ & 0 & $+14 \%$ & 0 & $+2 \%$ & 0 & $+8 \%$ & 0 \\
\hline $\begin{array}{l}6 \text { floors, Formwork } 11 \mathrm{~m} / \mathrm{s}, \\
\text { concrete } 15 \mathrm{~m} / \mathrm{s}\end{array}$ & $+14 \%$ & 2,9 & $+25 \%$ & 3,5 & $+2 \%$ & 0 & $+8 \%$ & 0 \\
\hline Baseline: 10 floors $(20 \mathrm{~m} / \mathrm{s})$ & $\pm 0 \%$ & 0 & $\pm 0 \%$ & 0 & $\pm 0 \%$ & 0 & $\pm 0 \%$ & 0 \\
\hline $\begin{array}{l}10 \text { floors, Formwork } 15 \mathrm{~m} / \mathrm{s} \text {, } \\
\text { concrete } 15 \mathrm{~m} / \mathrm{s}\end{array}$ & $+16 \%$ & 3,6 & $+11 \%$ & 0 & $+10 \%$ & 1,8 & $+5 \%$ & 0 \\
\hline $\begin{array}{l}10 \text { floors, Formwork } 11 \mathrm{~m} / \mathrm{s} \text {, } \\
\text { concrete } 15 \mathrm{~m} / \mathrm{s}\end{array}$ & $+32 \%$ & 17,6 & $+19 \%$ & 3,6 & $+12 \%$ & 4,9 & $+5 \%$ & 0 \\
\hline
\end{tabular}

